\title{
The Effects of Management Practices on Grassland Birds- Lark Sparrow (Chondestes grammacus)
}

Chapter DD of

The Effects of Management Practices on Grassland Birds

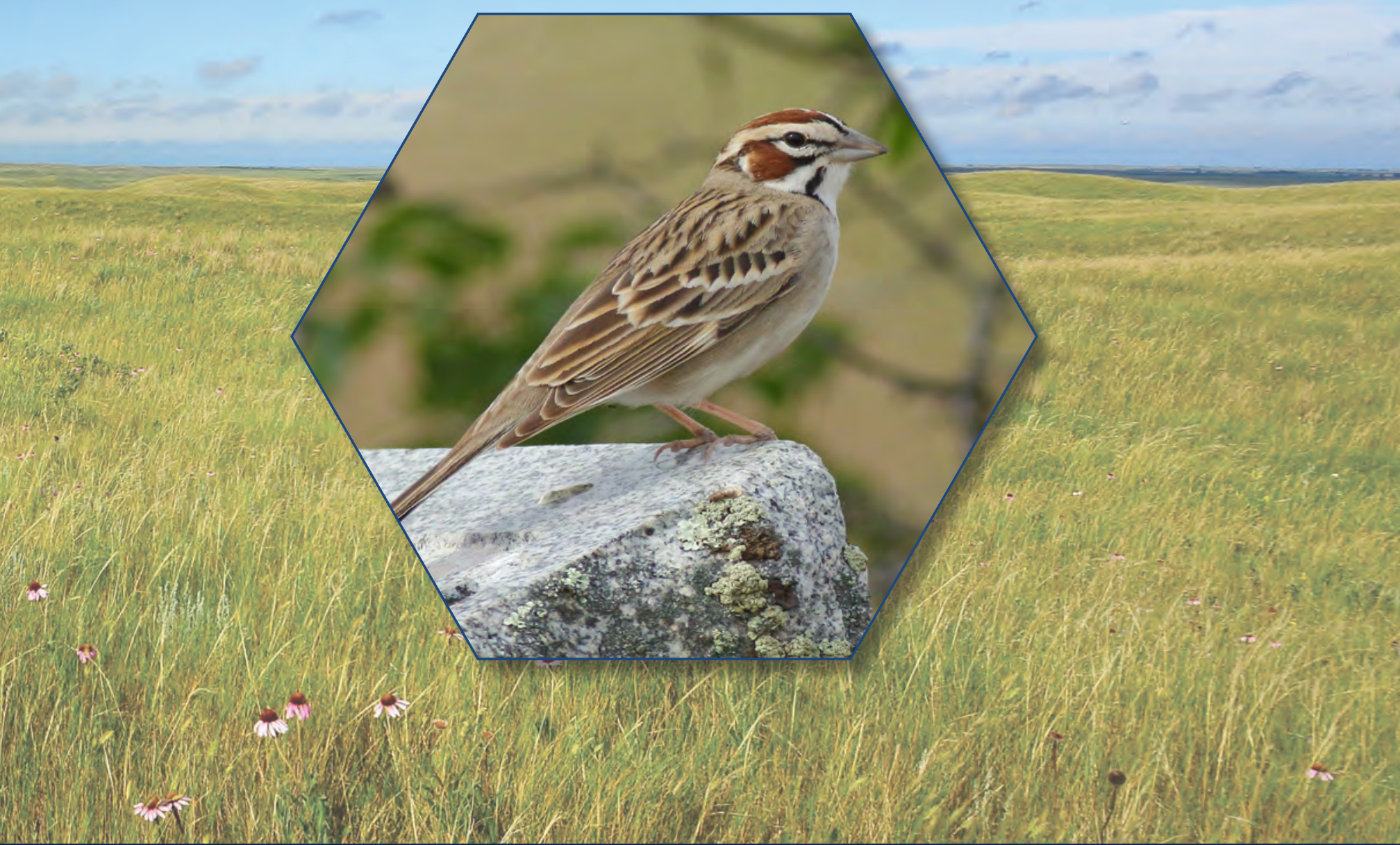

Professional Paper 1842-DD

U.S. Department of the Interior U.S. Geological Survey 
Cover. Lark Sparrow. Photograph by Keith Carlson, used with permission.

Background photograph: Northern mixed-grass prairie in North Dakota, by Rick Bohn, used with permission. 


\section{The Effects of Management Practices on Grassland Birds - Lark Sparrow (Chondestes grammacus)}

By Jill A. Shaffer, ${ }^{1}$ Lawrence D. Igl,, Douglas H. Johnson,, Marriah L. Sondreal, ${ }^{1}$ Christopher M. Goldade, ${ }^{1,2}$ Barry D. Parkin, ${ }^{1}$ and Betty R. Euliss ${ }^{1}$

Chapter DD of

The Effects of Management Practices on Grassland Birds

Edited by Douglas H. Johnson, ${ }^{1}$ Lawrence D. Igl, ${ }^{1}$ Jill A. Shaffer, ${ }^{1}$ and John P. DeLong1,3

${ }^{1}$ U.S. Geological Survey.

${ }^{2}$ South Dakota Game, Fish and Parks (current).

${ }^{3}$ University of Nebraska-Lincoln (current).

Professional Paper 1842-DD 


\section{U.S. Geological Survey, Reston, Virginia: 2021}

For more information on the USGS — the Federal source for science about the Earth, its natural and living resources, natural hazards, and the environment-visit https://www.usgs.gov or call 1-888-ASK-USGS.

For an overview of USGS information products, including maps, imagery, and publications, visit https://store.usgs.gov.

Any use of trade, firm, or product names is for descriptive purposes only and does not imply endorsement by the U.S. Government.

Although this information product, for the most part, is in the public domain, it also may contain copyrighted materials as noted in the text. Permission to reproduce copyrighted items must be secured from the copyright owner.

Suggested citation:

Shaffer, J.A., Igl, L.D., Johnson, D.H., Sondreal, M.L., Goldade, C.M., Parkin, B.D., and Euliss, B.R., 2021, The effects of management practices on grassland birds_-Lark Sparrow (Chondestes grammacus), chap. DD of Johnson, D.H., Igl, L.D., Shaffer, J.A., and DeLong, J.P., eds., The effects of management practices on grassland birds: U.S. Geological Survey Professional Paper 1842, 21 p., https://doi.org/10.3133/pp1842DD.

ISSN 2330-7102 (online) 


\section{Contents}

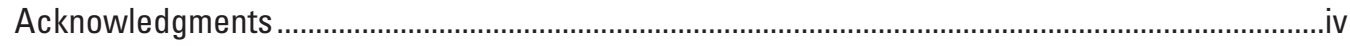

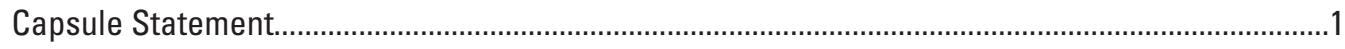

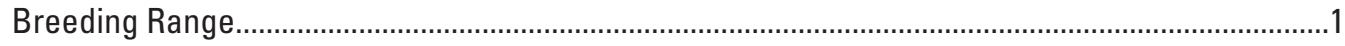

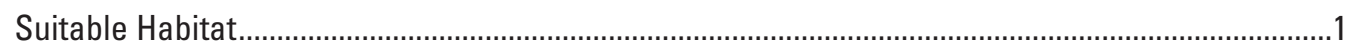

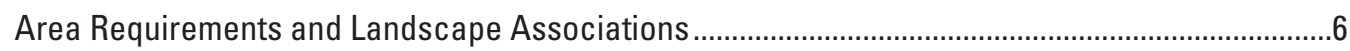

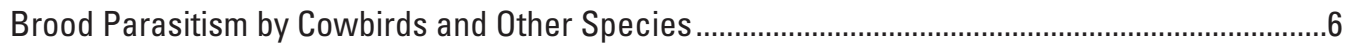

Breeding-Season Phenology and Site Fidelity ........................................................................

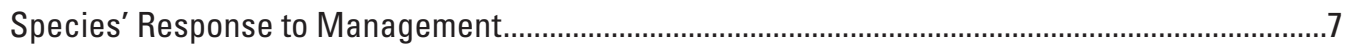

Management Recommendations from the Literature ……...........................................................

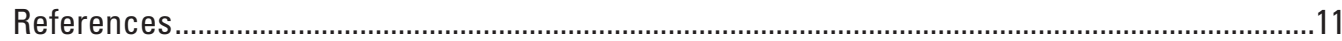

\section{Figure}

DD1. The breeding distribution of the Lark Sparrow (Chondestes grammacus) in the United States and southern Canada, based on North American Breeding Bird Survey data, 2008-12

\section{Table}

DD1. Measured values of vegetation structure and composition in Lark Sparrow (Chondestes grammacus) breeding habitat by study...

\section{Conversion Factors}

International System of Units to U.S. customary units

\begin{tabular}{lll}
\hline \multicolumn{1}{c}{ Multiply } & \multicolumn{1}{c}{ By } & \multicolumn{1}{c}{ To obtain } \\
\hline centimeter $(\mathrm{cm})$ & Length & \\
meter $(\mathrm{m})$ & 0.3937 & inch (in.) \\
kilometer $(\mathrm{km})$ & 3.281 & foot $(\mathrm{ft})$ \\
\hline & 0.6214 & mile (mi) \\
\hline square meter $\left(\mathrm{m}^{2}\right)$ & Area & \\
hectare (ha) & 0.0002471 & acre \\
hectare (ha) & 2.471 & acre \\
\hline
\end{tabular}




\section{Abbreviations}

2,4,5-T 2,4,5-Trichlorophenoxyacetic acid

AUM animal unit month

BBS Breeding Bird Survey

CRP Conservation Reserve Program

DDT dichlorodiphenyltrichloroethane

spp. $\quad$ species (applies to two or more species within the genus)

\section{Acknowledgments}

Major funding for this effort was provided the Prairie Pothole Joint Venture, the U.S. Fish and Wildlife Service, and the U.S. Geological Survey. Additional funding was provided by the U.S. Forest Service, The Nature Conservancy, and the Plains and Prairie Potholes Landscape Conservation Cooperative. We thank the following cooperators who provided access to their bibliographic files: Louis B. Best, Carl E. Bock, Brenda C. Dale, Stephen K. Davis, James J. Dinsmore, Fritz L. Knopf (deceased), Rolf R. Koford, David R. C. Prescott, Mark R. Ryan, David W. Sample, David A. Swanson, Peter D. Vickery (deceased), and John L. Zimmerman. We thank Christopher M. Goldade for his illustration of the Lark Sparrow and the U.S. Geological Survey's Patuxent Wildlife Research Center, Laurel, Maryland, for providing the range map. We thank Courtney L. Amundson, Joel S. Brice, Rachel M. Bush, James 0. Church, Shay F. Erickson, Silka L.F. Kempema, Emily C. McLean, Susana Rios, Bonnie A. Sample, and Robert O. Woodward for their assistance with various aspects of this effort. Lynn M. Hill and Keith J. Van Cleave, U.S. Geological Survey, acquired many publications for us throughout this effort, including some that were very old and obscure. Earlier versions of this account benefitted from insightful comments from Jane E. Austin, John W. Martin, Dan L. Reinking, and Brian A. Tangen. 


\title{
The Effects of Management Practices on Grassland Birds-Lark Sparrow (Chondestes grammacus)
}

\author{
By Jill A. Shaffer, ${ }^{1}$ Lawrence D. Igl,, Douglas H. Johnson,, Marriah L. Sondreal,, Christopher M. Goldade, ${ }^{1,2}$ \\ Barry D. Parkin, ${ }^{1}$ and Betty R. Euliss ${ }^{1}$
}

\section{Capsule Statement}

Keys to Lark Sparrow (Chondestes grammacus) management include providing open grasslands with sparse-tomoderate herbaceous and litter cover and a woody component and allowing occasional burning or moderate grazing. Lark Sparrows have been reported to use habitats with 10-63 centimeters $(\mathrm{cm})$ average vegetation height, $10-54$ percent grass cover, 9-25 percent forb cover, 4-18 percent shrub cover, 16-38 percent bare ground, $12-45$ percent litter cover, and less than or equal to $(\leq) 1 \mathrm{~cm}$ litter depth. The descriptions of key vegetation characteristics are provided in table DD1 (after the "References" section). Vernacular and scientific names of plants and animals follow the Integrated Taxonomic Information System (https://www.itis.gov).

\section{Breeding Range}

Lark Sparrows breed from southern British Columbia to southern Manitoba; south to southern California and southern Texas; and east to western North Carolina, western Ohio, and southern Michigan (National Geographic Society, 2011). Historically, the species' breeding range was limited to western North America, but it expanded northward with the settlement of the prairies (Houston and Houston, 2001) and eastward with the clearing of forests (Fortin and others, 2005). The relative densities of Lark Sparrows in the United States and southern Canada, based on North American Breeding Bird Survey (BBS) data (Sauer and others, 2014), are shown in figure DD1 (not all geographic places mentioned in report are shown on figure).

\section{Suitable Habitat}

The Lark Sparrow is a habitat generalist that inhabits grasslands containing or adjoining scattered trees and shrubs

${ }^{1}$ U.S. Geological Survey.

${ }^{2}$ South Dakota Game, Fish and Parks (current). 


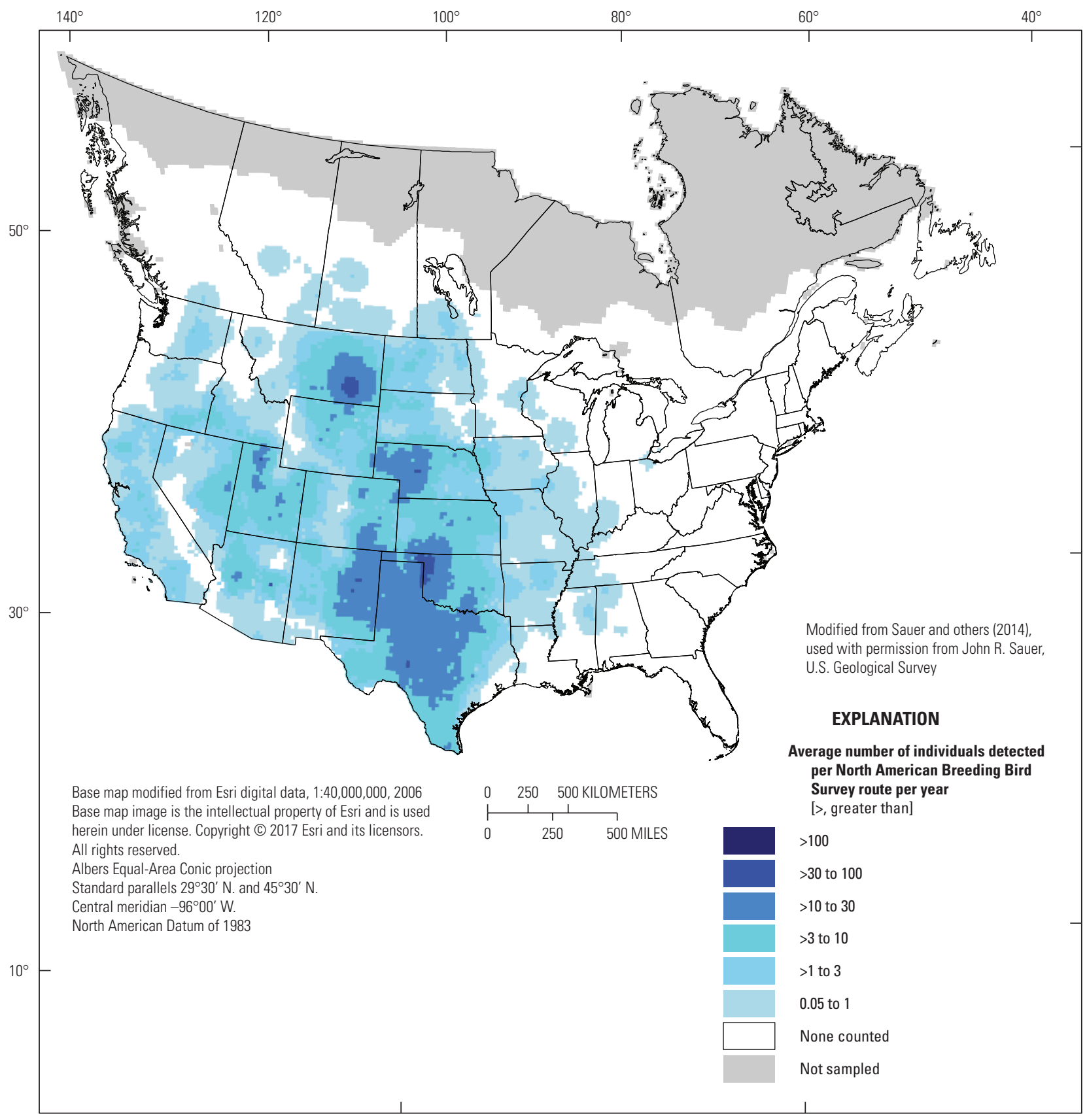

Figure DD1. The breeding distribution of the Lark Sparrow (Chondestes grammacus) in the United States and southern Canada, based on North American Breeding Bird Survey (BBS) data, 2008-12. The BBS abundance map provides only an approximation of breeding range edges.

Holoubek and Jensen, 2015; Young and others, 2015), wooded draws, windbreaks, shrub thickets, lowland forests, and pine (Pinus)-juniper (Juniperus) woodlands (Walcheck, 1970; Stewart, 1975; Salt and Salt, 1976; Faanes, 1983; Wershler and others, 1991; Cable and others, 1992; Faanes and Lingle, 1995; Pavlacky and others, 2012; Fleishman and others, 2014; Drilling and others, 2016). Suitable habitats also include riparian habitats and wet meadows (Helzer, 1996; Prescott, 1997; Helzer and Jelinski, 1999; Tsai and others, 2012). The species inhabits edges between habitat patches, such as those between woodland and grasslands; successional habitats, such as oldfields (that is, idle or neglected arable lands that have naturally reverted back to perennial cover) (Rising, 1974; Dinsmore and others, 1984; Wershler and others, 1991; Zimmerman, 1993; Best, 2001; Martin and Parrish, 2020); cultivated and weedy fields (Newman, 1970; Stewart, 1975; Walley, 1985); blacktailed prairie dog (Cynomys ludovicianus) colonies (Barko and others, 1999; Tyler and Shackford, 2002; Smith and Lomolino, 2004; Goguen, 2012); and residential areas (Baepler, 1968; Salt and Salt, 1976). 
In western Canada and western United States, the Lark Sparrow readily uses sagebrush habitats. In British Columbia and Washington, Knight and others (2016) categorized the Lark Sparrow as a sagebrush specialist. Within shrubsteppe habitats in British Columbia, Lark Sparrow abundance was negatively related to ponderosa pine (Pinus ponderosa) density (Krannitz, 2007), and Lark Sparrows preferred habitats with more bare soil and less grass cover (Krannitz and Rohner, 2000). In southeastern Washington, Lark Sparrow abundance was higher in areas of big sagebrush (Artemisia tridentata) than in areas of threetip sagebrush (Artemisia tripartita), native bluebunch wheatgrass (Pseudoroegneria spicata), or invasive cheatgrass (Bromus tectorum) (Earnst and others, 2009; Earnst and Holmes 2012). In another study in southeastern Washington, soil type and range condition of shrubsteppe communities did not affect Lark Sparrows (Vander Haegen and others, 2000). No significant differences in Lark Sparrow abundance were detected among loamy, sandy, or shallow soils and range conditions of good, fair, and poor. Throughout southern and central Idaho, Lark Sparrow occupancy was highest at higher values of shrub height and variability in this height and at moderate levels of shrub coverage. In Oregon and Nevada, Lark Sparrow abundance was positively related to sagebrush cover (Wiens and Rotenberry, 1981). In Nevada, Lark Sparrows preferred crested wheatgrass (Agropyron cristatum) plantings that were invaded by sagebrush more so than areas that were dominated solely by sagebrush or crested wheatgrass; Lark Sparrow abundance was negatively associated with sagebrush density (McAdoo and others, 1989). In southeastern Arizona, Andersen and Steidl (2019) found that Lark Sparrow occupancy peaked at 15 percent woody cover; occupancy was lower below and above 15 percent woody cover. In another Arizona study, Bock and Webb (1984) observed that Lark Sparrows usually flushed near mesquite (Prosopis juliflora). In northwestern New Mexico, Lark Sparrows inhabited grasslands dominated by big sagebrush and pinyon pine (Pinus edulis)-Utah juniper (Juniperus osteosperma) woodlands (Ortega and Francis, 2012). In northeastern New Mexico, Lark Sparrows used shortgrass prairies interspersed with broom snakeweed (Gutierrezia sarothrae), pricklypear cactus (Opuntia spp.), fringed sagebrush (Artemisia frigida), cane cholla (Cylindropuntia imbricata), and fourwing saltbush (Atriplex canescens) (Goguen, 2012).

Throughout the Great Plains, the Lark Sparrow inhabits grasslands with a woody component. In Alberta, Lark Sparrows occupy semi-open grasslands and parklands, particularly ecotones between grassland and areas dominated by eastern cottonwood (Populus deltoides) and sagebrush, such as found in river valleys, coulees, and sandhills, as well as at the edge of cultivated uplands, but are absent on open prairies (Rand, 1948; Salt and Salt, 1976; Wershler and others, 1991). In southern Manitoba, Taylor (2018) described the species' habitat as lightly wooded, sandy terrain, whereas Maher (1974) wrote that the Lark Sparrow was an uncommon resident of wooded and brushy coulees. In Montana, Lark
Sparrows inhabit mixed-grass prairies, badlands, pine-juniper woodlands with a sagebrush and greasewood (Sarcobatus vermiculatus) component, and big sagebrush shrubsteppe (Cameron, 1908; Walcheck, 1970; Bock and Bock, 1987). In North Dakota, Lark Sparrows inhabit weedy fields and grassland/woodland edges that include some woody vegetation, including Rocky Mountain juniper (Juniperus scopulorum), green ash (Fraxinus pennsylvanica), bur oak (Quercus macrocarpa), chokecherry (Prunus virginiana), red-fruited hawthorn (Crataegus chrysocarpa), silver buffaloberry (Shepherdia argentea), Woods' rose (Rosa woodsii), and silver sagebrush (Artemisia cana) (Stewart, 1975). In South Dakota, Lark Sparrows primarily use edge habitats near woodlots, shelterbelts, and pastures (Drilling and others, 2016). Sieg (1991) recorded the species within Rocky Mountain juniper woodlands in Badlands National Park in South Dakota, and Pavlacky and others (2012) recorded the species within the ponderosa pine forests along the South Dakota and Wyoming border.

Along the Platte River in Nebraska, Faanes and Lingle (1995) observed the species most often in native grasslands that were experiencing encroachment by Rocky Mountain juniper and that contained an abundance of soapweed yucca (Yucca glauca). In wildlife management areas in southern Nebraska, Stuber and Fontaine (2018) estimated that the ideal proportion of grassland and woodland for Lark Sparrows was 0.53 and 0.31 , respectively. Williams and others (2011) examined the relationship between Lark Sparrow density and rangeland ecological-site characteristics for Colorado shrubsteppe habitats. Lark Sparrow densities were highest in loamy and sandy soils that were characterized by opencanopy plant communities with short (less than $[<] 100 \mathrm{~cm}$ ), scattered shrubs. Lark Sparrows were rarely found in saline lowland sites characterized by tall, dense shrubs. The species responded more strongly to the horizontal and vertical characteristics of the plant communities than to species composition (Williams and others, 2011). Within the Nebraska Sandhills, Lark Sparrow abundance was most strongly related to ecological sites; abundance was highest at 5 birds per plot on choppy sands ecological sites, 3 birds on sands or choppy sands complex sites, $<2.5$ birds on sands ecological sites, and $<2$ birds on sandy ecological sites (Sliwinski and others, 2019).In Colorado, Kansas, Nebraska, and Oklahoma, Lark Sparrow occurrence was 11 percent in shortgrass prairies and 4 percent in both dryland agriculture and Conservation Reserve Program (CRP) fields; mean occurrence of Lark Sparrows was greatest in grasslands where greater than (>) 75 percent of the grass was taller than $15 \mathrm{~cm}$ and shrub coverage was 3-10 percent (McLachlan, 2007). In the sand sagebrush (Artemisia filifolia) grasslands of northwestern Oklahoma, Lark Sparrow abundance was negatively related to vegetation height and positively related to coverage of dead eastern redcedar (Doxon, 2009).

Within the Rolling Plains ecoregion of the Texas Panhandle, a transition zone between mixed-grass and shortgrass prairies, Lark Sparrows inhabit grasslands invaded by woody 
The Effects of Management Practices on Grassland Birds—Lark Sparrow (Chondestes grammacus)

plants and forbs such as honey mesquite (Prosopis glandulosa), cholla cactus (Cylindropuntia spp.), catclaw mimosa (Mimosa aculeaticarpa), sand sagebrush, pricklypear (Opuntia phaeacantha), common broomweed (Amphiachyris dracunculoides), and soapweed yucca (Long and others, 2012; Roberts and others, 2012; Tsakiris and others, 2013). In central Texas, Lark Sparrows inhabit areas with tobosagrass (Hilaria mutica) and an overstory of honey mesquite and lotebush (Ziziphus obtusifolia) (Renwald, 1977). In southern Texas, Lark Sparrows inhabit grassland and mesquite woodlands (Davis and others, 2019). In southern Texas mixed-brush shrublands, Lark Sparrows were 73 percent more abundant on areas in which $>50$ percent of grass species were native compared to areas in which $>50$ percent of grass species were nonnative (Flanders and others, 2006). In another southern Texas study, Lark Sparrow occurrence increased 27 percent for every 10 percent increase in tanglehead (Heteropogon contortus), a native grass species that has invaded and become dominant in areas with clay loam soils (Bielfelt, 2013).

Throughout their range, Lark Sparrows commonly inhabit savanna habitats. Within the tallgrass prairies of the Sheyenne National Grassland of North Dakota, Lark Sparrows were most likely to occur in bur oak savannas containing $<40$ percent tree coverage within 200-meter (m) belt transects (Cunningham and Johnson, 2012). In open landscapes in the Sheyenne National Grassland, Lark Sparrow probability of occurrence increased in response to increasing levels of proximate tree cover (that is, within $100 \mathrm{~m}$ around sample locations), whereas in wooded landscapes, probability of occurrence decreased in response to increasing levels of proximate tree cover (Cunningham and Johnson, 2011, 2016). In the Anoka Sandplains of Minnesota, Lark Sparrows inhabited oak savannas and woodlands dominated by bur oak, northern pin oak (Quercus ellipsoidalis), and northern red oak (Quercus rubra) (Davis and others, 2000; Au and others, 2008; Davis and Miller, 2018). In Wisconsin, Lark Sparrows inhabited oak savannas (defined as 5-50 percent tree cover) and woodlands ( $>50$ percent tree cover) dominated by bur oak, pin oak, red oak, white oak (Quercus alba), black oak (Quercus velutina), jack pine (Pinus banksiana), and black cherry (Prunus serotina) (Wood and others, 2011; Bar-Massada and others, 2012; Vos and Ribic, 2013). In the Cross Timbers ecoregion of Kansas, Lark Sparrow occupancy in oak savannas declined as shrub density within $50 \mathrm{~m}$ of point counts increased, indicating a preference for savannas (defined as 1-25 percent canopy cover) over woodlands (25-60 percent canopy cover); dominant oak species were blackjack oak (Quercus marilandica) and post oak (Quercus stellata) (Holoubek and Jensen, 2015). In northern Texas, Lark Sparrows occupied shrubland savanna pastures dominated by honey mesquite and lotebush (Lee, 2006). In California, oak woodlands occupied by Lark Sparrows were dominated by blue oak (Quercus douglasii) (Young and others, 2015).

In the eastern portion of their range, Lark Sparrows are generally considered a species of transitional and marginal habitats, such as the edges between agricultural fields and brushy and sandy grasslands (Graber and Graber, 1963; Dinsmore and others, 1984; Best, 2001). In Nebraska, Puckett and others (2009) determined the primary use area (that is, the functional edge) for birds foraging in crop fields adjacent to woody edges; Lark Sparrows foraged in crop fields at all five distances $(0-10,10-20,20-30,30-40$, and $40-50 \mathrm{~m})$ outward from adjacent woody edges but typically foraged near the edge within 10-20 m.

Lark Sparrows are occasionally found in fields enrolled in the CRP or Permanent Cover Program or in fields of dense nesting cover (Johnson and Schwartz, 1993; Hull and others, 1996; Best and others, 1997; Klute and others, 1997; McMaster and Davis, 1998; McLachlan, 2007; Riffell and others, 2008, 2010; Igl, 2009). In north-central Missouri, Lark Sparrows were reported using CRP fields planted to cool-season grasses and CRP fields planted to warm-season grasses (McCoy and others, 2001). In Nebraska, Kansas, and Missouri, Lark Sparrow abundance was negatively related to patch density of CRP grass-based practices (as opposed to tree-based practices) and negatively related to recently established CRP grass habitat where succession had not yet progressed beyond an early seral stage ( $<4$ years since establishment), indicating a preference for clumped arrangements of CRP habitat and older CRP habitat, respectively (Riffell and others, 2010). In Colorado, Kansas, Nebraska, and Oklahoma, McLachlan (2007) found that Lark Sparrows were significantly more abundant in shortgrass prairies than in CRP grasslands that were planted to tame or native grass and legume species (plant species not provided). In south-central Kansas (Hickman and others, 2006) and northcentral Oklahoma (Chapman and others, 2004; George and others, 2013), Lark Sparrows were more abundant in native mixed-grass prairies than in CRP fields planted to monocultures of tame yellow bluestem (Bothriochloa ischaemum).

Lark Sparrows place their nests on the ground or close to the ground in woody vegetation (Ely, 1957; Baepler, 1968; Newman, 1970; McNair, 1985). Ground nests may be located in areas of sparse ground cover such as those areas associated with burning, moderate-to-heavy grazing, and poor or eroded soils (Fitch, 1958; Graber and Graber, 1963; Baepler, 1968; Kahl and others, 1985; Walley, 1985; Sample, 1989; Zimmerman, 1993; Prescott, 1997; Grigore, 1999), or in idle fields, lawns, and cemeteries (Baepler, 1968; Salt and Salt, 1976; Walley, 1985). Ground nests often are placed at the base of a plant (Rand, 1948; Ely, 1957; Baepler, 1968; Rising, 1974). In Montana, Cameron (1908) found an unspecified number of nests within pine hills, badlands, and open mixed-grass prairies and remarked that nests were always under sagebrush. Also in Montana, Walcheck (1970) found seven of eight nests placed under big sagebrush and observed that the granular soil under big sagebrush was a characteristic of the species' nest site; the eighth nest was placed under greasewood. In North Dakota mixed-grass pastures, Lark Sparrows built their nests in areas with greater litter depth than was available at random points, but daily nest survival declined with an increase in litter depth (Mack, 2017). A habitat simulation model produced by Lusk and others (2003) for Lark Sparrows 
in Oklahoma grazed mixed-grass prairies characterized nest sites as areas with $<87$ percent bare ground, $<74$ percent litter cover, and $>9$ percent structural vegetation cover (that is, plants that provided suitable nesting substrates); and that were $<270 \mathrm{~cm}$ away from structural elements (that is, any plant that provided nesting structure similar to woody plants, regardless of whether the plant was woody or herbaceous). Successful nest sites had less bare ground cover and more litter cover than unsuccessful nests (means of 6 compared with 17.5 percent and 18 compared with 10 percent, respectively). In an Oklahoma study within oldfields, tame pastures, and residential lawns, five of 13 nests were placed on the ground and 8 were placed in woody vegetation $<4 \mathrm{~m}$ above the ground (Ely, 1957). In Oklahoma tallgrass prairies, 14 Lark Sparrow nests were built from 0 to $210 \mathrm{~cm}$ above the ground (Reinking and others, 2009). In Oklahoma sand sagebrush grasslands, ground-nesting Lark Sparrow nests had higher grass, forb, shrub bare ground, and live vegetation cover and less litter and shorter plant height than random sites (Doxon, 2009).

Above-ground nests may be in various species of shrubs, saplings, small trees, and cactus (Baepler, 1968; Newman, 1970; McNair, 1985; Igl and Kantrud, 2003; Suedkamp Wells and Fuhlendorf, 2005; Doxon, 2009; Long and others, 2012). In Ohio oak (Quercus spp.) savannas, Grigore (1999) reported that litter cover and vegetation density were the major determinants of successful Lark Sparrow nests. Successful nests had a median of 9 percent grass cover, 19 percent dewberry (Rubus spp.) cover, $<51$ percent bare ground cover, and $<20$ percent shrub cover; an average of 6.5 percent litter cover; and higher vegetation density than unsuccessful nests. In sand sagebrush grasslands, tree-nesting Lark Sparrows nests had higher forb, shrub, and live vegetation cover and visual obstruction readings than random sites, but lower grass cover; the species nested within the skeletons of dead cedar trees (Doxon, 2009). In a shrubland savanna pasture in northern Texas, Lark Sparrow nest sites had higher visual obstruction and lower percentage grass cover than random sites; successful (fledged at least one Lark Sparrow young) nests had lower percentage grass cover than unsuccessful nests (Lee, 2006). In a nesting study of four vegetation types in southern Texas, Davis and others (2019) found Lark Sparrows nesting in early-seral vegetation (for example, doveweed [Croton spp.], sandbur [Cenchrus spp.], and spotted beebalm [Monarda punctata]), native grasslands (for example, arrowfeather threeawn [Aristida purpurascens], Pan American balsamscale [Elionurus tripsacoides], and seacoast bluestem [Schizachyrium scoparium variety littorale]), and honey mesquite woodlands (woody plants $>3 \mathrm{~m}$ tall), but no nests were found within catclaw acacia (Senegalia greggii) shrublands (woody plants $<3 \mathrm{~m}$ tall). Two nests have been reported in humanmade structures: one nest in a hollow formed by the attachment point of a metal brace to a fence post (McNair, 1984) and one nest in a hollow formed in the ledge of structural channel beam in a carport (Johnson and others, 2016).
The future distribution of Lark Sparrows and their breeding habitat may be affected by climate-induced changes to temperature and precipitation (Langham and others, 2015). Under projected greenhouse gas emission scenarios described by the Intergovernmental Panel on Climate Change (2000), Langham and others (2015) categorized the Lark Sparrow as a climate-stable species, indicating that the species would retain more than 50 percent of its current distribution by 2050 across all Intergovernmental Panel on Climate Change scenarios, with potential for range expansion. Using a combination of BBS, eBird (https://ebird.org; Sullivan and others, 2009), and point-count data, Nixon and others (2016) modeled the impact of future climate-change scenarios on Lark Sparrow breeding distribution along the boreal forest-prairie ecotone in Alberta. Nixon and others (2016) predicted that the Lark Sparrow's breeding range would expand by 50 percent and that expansion largely would occur northward, originating in the Parkland Region of Alberta, with little southward expansion. In California, Jongsomjit and others (2013) projected that a future increase in temperature, reduction in annual precipitation, and increase in housing densities would decrease Lark Sparrow occurrence. Fleishman and others (2014) estimated the current location, quality, and connectivity of habitat for Lark Sparrows in four mountain ranges in the central Great Basin and projected the future location, quality, and connectivity of habitat for the species given different scenarios of climate-induced land-cover change. The area occupied by Lark Sparrow was projected to increase by $>25$ percent given a scenario of expansion of pinyon-juniper woodland by the year 2100 .

Spatial and temporal variation in precipitation and temperature may affect the occurrence and distribution of Lark Sparrows. Using BBS data from the Badlands and Prairies Bird Conservation Regions, Gorzo and others (2016) reported that Lark Sparrow abundance was not significantly related to a standardized temperature index or standardized precipitation index for the same year and the previous year. Using BBS and standardized precipitation evapotranspiration index data for the South Central Semi-Arid Prairies ecoregion, Cady and others (2019) reported that Lark Sparrow presence and the probability of local colonization or extinction in the ecoregion were not related to drought conditions. Tingley and others (2012) compared historical bird survey, temperature, and precipitation data gathered in the early 20 th century to BBS data and current climate data to evaluate elevational breeding range shifts within three regions of the Sierra Nevada Mountains; they concluded that Lark Sparrows shifted >1 kilometer $(\mathrm{km})$ upslope within the two regions that they occupied. Travers and others (2015) compared historical bird data on species' springarrival dates in eastern North Dakota in the early to mid-20th century to dates in the early 21 st century and concluded that Lark Sparrows were arriving later in the recent period than in the historical period. 
The Effects of Management Practices on Grassland Birds-Lark Sparrow (Chondestes grammacus)

\section{Area Requirements and Landscape Associations}

Male Lark Sparrow are strongly territorial near the nest during peak courtship, nest-site selection and construction, egg laying, and early incubation (Martin and Parrish, 2020). Thus, their territories are relatively small. In Kansas, estimated territory sizes for three male Lark Sparrows ranged from 0.0066 to 0.0248 hectares (ha), although one pair was observed occupying 6.3 ha (Fitch, 1958; Martin and Parrish, 2020). In oak openings in Ohio, male territory sizes ranged from 0.40 to 1.21 ha (Grigore, 1999).

Lark Sparrows have variable responses to patch size and landscape fragmentation. No studies have investigated a relationship between patch size and nest success or patch size and rates of brood parasitism by Brown-headed Cowbirds (Molothrus ater). In a study evaluating the effects of agricultural fragmentation on shrubsteppe bird communities in British Columbia in Canada and Washington in the United States, Knight and others (2016) found that Lark Sparrows were a weak indicator of edge habitat, which is consistent with the species' known preference for ecotones and disturbed areas. In North Dakota mixed-grass pastures, Lark Sparrows avoided selecting nest sites in edges between prairie dog colonies and woody cover (Mack, 2017). In Colorado, Lark Sparrows occurred more frequently on interior plots (more than $200 \mathrm{~m}$ from edge) than on edge plots (the interface between suburban development and upland or lowland habitats), but the difference was not significant because of high variation in numbers of Lark Sparrows among plots (Bock and others, 1999). In a 2-year study in Colorado, Kansas, Nebraska, and Oklahoma, Lark Sparrow response to landscape variables was inconsistent between years (McLachlan, 2007). Lark Sparrow occurrence was positively related to the amount of woodland in the surrounding landscape at the spatial scales of $600,1,200$, and $2,400 \mathrm{~m}$ in both years and $300 \mathrm{~m}$ in the first year; positively related to the number of land-cover patches in the surrounding landscape at all spatial scales in the second year; and negatively related to the amount of grassland at all spatial scales in the first year. In western Oklahoma, species occurrence models indicated that high shrubland and cropland cover within $800 \mathrm{~m}$ of BBS stops were indicators of Lark Sparrow occurrence (Coppedge and others, 2004). In an oak savanna in northwestern Ohio, Coulter (2008) assessed Lark Sparrow habitats at three scales (landscape, habitat patch, and territory), and found that Lark Sparrows responded to different habitat parameters at different spatial scales. At the landscape scale, habitat patch size and shape were important; habitat patch size was larger and perimeter-to-area ratio was lower in sites occupied by breeding Lark Sparrows than in former breeding sites no longer occupied by the species. At the habitat patch scale, percent tree cover was lower and vegetation height-density was higher in occupied sites than in currently unoccupied sites. At the territory scale, percent tree cover, percent shrub cover, vegetation height-density, and distance to closest occupied territory were lower in occupied territories than in areas in which Lark Sparrows were absent (Coulter, 2008).

\section{Brood Parasitism by Cowbirds and Other Species}

Lark Sparrows are a common host of the Brown-headed Cowbird (Friedmann and others, 1977; Martin and Parrish, 2020) and also may be a host of the Bronzed Cowbird (Molothrus aeneus) in the southwestern United States and Mexico (Martin and Parrish, 2020). Rates of brood parasitism vary from 0 percent of 18 nests (Erickson, 2017) to 82 percent of 11 nests (Hill, 1976). Rates of cowbird brood parasitism for Lark Sparrow are summarized in Shaffer and others (2019). Lark Sparrows may be multiply parasitized (Newman, 1970; Igl and Johnson, 2007). Abandonment of parasitized nests has been reported by Baepler (1968) and Walley (1985).

In a phenomenon that McNair (1984) termed "protoparasitism," Lark Sparrows may attempt to share nests built by other species and may end up raising young of these other species. Conversely, the host species may evict the adult Lark Sparrows and raise the young Lark Sparrows alongside the host young (McNair, 1984). Nest-sharing generally results in a high rate of nest failure. Ellison and others (2013) documented a potential case of intraspecific nest parasitism, in which a young Lark Sparrow was not genetically related to the adult female attending the nest. For unknown reasons, individual Lark Sparrows occasionally reuse their own or other Lark Sparrow's nests from previous years (McNair, 1984), as well as old nests of other species (Martin and Parrish, 2020).

\section{Breeding-Season Phenology and Site Fidelity}

Lark Sparrows are migratory and arrive on their southern breeding grounds as early as mid-March and on their northern breeding grounds from mid-April to May (Cameron, 1908; Fitch, 1958; Maher, 1974; Stewart, 1975; Dinsmore and others, 1984; Walley, 1985; Zimmerman, 1993; Martin and Parrish, 2020). Lark Sparrows depart for their wintering grounds in the southern United States and Mexico from midto late September (Maher, 1974; Dinsmore and others, 1984; Walley, 1985; Martin and Parrish, 2020). Some Lark Sparrows may depart as early as mid-July or as late as mid-November (Dinsmore and others, 1984; Zimmerman, 1993; Martin and Parrish, 2020). Renesting attempts after a nest failure are common (Baepler, 1968; McNair, 1985; Martin and Parrish, 2020). Although no evidence exists (Baepler, 1968), some authors have suggested that double-broodedness occurs (Cameron, 1908; Newman, 1970; Joern, 1992; Kaspari and Joern, 1993). Klimkiewicz and Futcher (1987) reported that a banded bird 
was recaptured 8 years later at the same site where it was banded. Ross and others (2014) reported that 61.7 percent of 81 adults that were color-banded during a 4-year period returned to their Ohio breeding grounds. Ross and others (2014) also equipped 21 adult Lark Sparrows with light-level geolocators in 1 year to track their movements between their Ohio breeding grounds and their wintering grounds. Ten (47.6 percent) of the 21 Lark Sparrows tagged with geolocators were resighted on the breeding area during the following 2 years. Also in Ohio, nine (16.1 percent) of 56 banded fledglings returned to nest in their natal areas in oak savanna habitats (Grigore, 1999).

\section{Species' Response to Management}

Burning of habitats may be beneficial to Lark Sparrows, but the benefits may depend on habitat and the amount of time postburn. In Washington shrubsteppe, Lark Sparrow abundance increased the first year postburn but then declined to preburn levels or lower by the third year (Earnst and others, 2009). The authors suggested the increase in abundance in the first year after the burn could be attributed to an increase in bare ground. In Montana shrubsteppe, Lark Sparrows avoided a grassland burned 2 years previously that was devoid of woody vegetation, preferring instead an unburned grassland dominated by big sagebrush and specifically areas with little ground cover (Bock and Bock, 1987).

Studies encompassing a number of grassland biomes and conducted throughout the Great Plains to evaluate the effect of burning, often in concert with grazing, indicate the importance of periodic management in maintaining populations of Lark Sparrows. In the Nebraska Sandhills, Lark Sparrow abundance was similar between areas primarily burned during the dormant season and unburned areas within a pasture grazed by American bison (Bison bison) (Griebel and others, 1998). In a Kansas study of CRP fields planted to native grass species, abundance of Lark Sparrows was low on springburned fields and nearly zero on unburned fields (Robel and others, 1998). In the Oklahoma tallgrass prairies of the Flint Hills, Lark Sparrows were nearly equally abundant in the traditional annually spring-burned pastures stocked from mid-April to mid-July as they were in patch-burned pastures (that is, patches averaging 100 ha burned once in either spring or autumn every 3 years with cattle stocked at 1.2 ha per 270-kilogram steer) burned within the past 2 years, but Lark Sparrows were not found in burned patches that had not been disturbed for $>2$ years (Fuhlendorf and others, 2006). In the Tallgrass Prairie Preserve of Oklahoma, Patten and others (2006) reported that Lark Sparrows preferred nesting in tallgrass prairies more so than in roadsides, and more nests were located in burned (prescribed fire in spring followed by intensive grazing), and grazed prairies than in undisturbed prairies. However, Patten and others (2011) reported higher cowbird parasitism rates of Lark Sparrow nests in burned tallgrass prairies ( 16.7 percent parasitism of 18 nests) than in grazed-only and undisturbed tallgrass prairies ( 0 percent parasitism of 4 nests). In an Oklahoma study in sand sagebrush grasslands, Lark Sparrow abundance was five times higher in patch-burn pastures (that is, applying growing-season prescribed burns in a spatially and temporally variable mosaic and allowing livestock to select among burned and unburned patches in the landscape) than in traditional pastures (that is, summer-long grazing at 24.7 animal unit days per ha and no burning) (Doxon, 2009; Holcomb and others, 2014). Lark Sparrow density was highest in current-year burns. Nest survival was similar between patch-burn pastures and traditional pastures (Holcomb and others, 2014). Lark Sparrows initiated their nests earlier in the current-year burn patches than in the traditional patches and the other patch-burn patches (Doxon, 2009). Lark Sparrows nested 4 days earlier in current year burns than in $\geq 3$ years postburn patches, 8 days earlier than in 1-2 years postburn patches, and 12 days earlier than in traditional patches. Clutch sizes did not differ among years or time since burn but were higher in traditional patches than in patch-burn treatments (Doxon, 2009). Lark Sparrows fledged a higher proportion of nests in the patch-burn treatment, and no association was found between time since burn and cowbird parasitism rate. For sage-nesting Lark Sparrows, losses to weather were higher in burned patches than in unburned patches, and depredation was highest in traditional patches. Weather loss in cedar-nesting Lark Sparrows was highest in current-year burns, but depredation was the principal cause of nest failure among treatments. There was more variety in the causes of nest failure in thistle (Cirsium spp.)-nesting lark sparrows; however, depredation and weather were the most common cause of nest failure in all patches (Doxon, 2009).

Within Arizona desert grasslands, Lark Sparrow abundance increased in native vegetation 2 years postburn; abundance was positively correlated with percentage of herbaceous cover (Bock and Bock, 1992). A nonsignificant increase in abundance occurred 2 years postburn in fields composed of Lehmann lovegrass (Eragrostis lehmanniana) and weeping lovegrass (Eragrostis curvula). Lark Sparrows also were found 1-2 years postburn in tame grasslands, where they were absent before burning and 3-4 years postburn (Bock and Bock, 1988, 1992). In Arizona floodplains dominated by big sacaton (Sporobolus wrightii), there was no difference in Lark Sparrow abundance between burned and unburned stands (Bock and Bock, 1988). In a grassland of honey mesquite and tobosagrass in central Texas, Lark Sparrow abundance was highest in areas that had most recently been burned and decreased as litter and grass coverage increased (Renwald, 1977). Number of nests was negatively correlated to percentage cover of tobosagrass; Lark Sparrows nested in tobosagrass ranging from 32 to 55 percent cover. In Texas Panhandle shortgrass prairies encroached by honey mesquite and cholla cactus, daily nest survival was 1.55 times more likely in experimental units burned every 2 years during the dormant season than in units burned every 10 years and 1.4 times more likely than in units burned every 4 years (Long and 
others, 2012). Nest survival was not related to shrub density at nest sites. In that same study, Long and others (2014) found no significant differences in mean relative abundance of Lark Sparrows across three experimental treatments: burned every 2 years, burned every 4 years, and unburned controls. In the same area studied by Long and others $(2012,2014)$, Jacobson and others (2011) reported that daily survival of Lark Sparrow nests decreased with interval length (evaluated durations were every 2,4 , or 10 years) between dormant-season prescribed burn frequency and the date of the nesting season (Jacobson and others, 2011). In the Texas Panhandle but east of the studies of Long and others $(2012,2014)$ and Jacobson and others (2011), two large wildfires burned shortgrass and mixed-grass prairies in spring (Roberts and others, 2012, 2017). Lark Sparrow densities were higher in shortgrass prairies 2-3 years postburn (first and later summers were not included in analysis) than in unburned grasslands; in mixedgrass prairies, however, Lark Sparrow densities did not differ between burned and unburned grasslands (Roberts and others, 2012). Lark Sparrow nest success was greater on burned sites in the second summer than the third summer postburn. Forbs, woody vegetation, and bare ground were higher around nests in the second than in the third summer, but litter cover was higher in the third summer (Roberts and others, 2017). In a grazed shrubland savanna in northern Texas, Lark Sparrow abundance was negatively related to the number of years since the last burn; abundance increased with more brush cover and bare ground cover (Lee, 2006).

In east-central Minnesota, Lark Sparrow abundance increased after an oak savanna was restored using growingseason prescribed burns that reduced tree density and increased the abundance of dead trees (Davis and others, 2000; Davis and Miller, 2018). In a Missouri study examining avian composition within 53 sites spanning hardwood forests, oldfields, and grasslands, Lark Sparrows were found on only a single grassland site that was recently cleared of most trees and burned; the site was characterized by sparse litter coverage and few (24-50 stems per ha) woody stems greater or equal to $2.5 \mathrm{~cm}$ diameter at breast height (Kahl and others, 1985).

Lark Sparrows are common within grazed grasslands, and Lark Sparrow densities appear to be unaffected by grazing system or species of grazing mammal. In North Dakota mixed-grass pastures, Lark Sparrows reached their highest densities in a transitional pasture (that is, a pasture in which black-tailed prairie dog occupancy was reduced because of an unplanned reduction by poisoning) and their lowest densities in a pasture with no black-tailed prairie dogs (Mack, 2017; Geaumont and others, 2019). In the north-central portion of the Nebraska Sandhills, Kempema (2007) examined the effect of grazing-system duration on Lark Sparrow density. Average values during the growing season (May 1 to September 30 ) for short duration grazing system was a rotation of 3 days of grazing at 1.4 animal unit months (AUMs) per ha; medium duration was 23 days at 1.3 AUMs per ha, and long duration was 78 days at 1.4 AUMs per ha. Lark Sparrow density was not significantly affected by grazing system, but the highest density occurred on the long-duration grazing system and lowest on the medium-duration system. The model providing the best explanation for variation in density included growing-season stocking rate and the amount of shrub, prostrate litter, and bare soil (Kempema, 2007). Within the same area of the Nebraska Sandhills, Sliwinski and others $(2019,2020)$ examined the relationship between five grazing systems (season-long continuous, deferred rotation, management intensive, dormant season only, fixed rotation) and avian diversity. Lark Sparrows were among the five most common bird species within the study area. Sliwinski and others $(2019,2020)$ reported that grazing system did not influence avian community structure more than the management unit (that is, the individual ranch), and this finding was probably not related to grazing management but rather was related to landscape features (such as, distance to wetlands, forests, or shrubs). In another Nebraska study in the county east of the studies conducted by Kempema (2007) and Sliwinski and others (2020), Lark Sparrow abundance was higher on an area both burned and grazed year-round by American bison at 1.2 AUMs per ha than on an area grazed by cattle at 1 AUM per ha from May 15 to November 15 (Griebel and others, 1998). In shortgrass prairies in northern Colorado, Wilkins and others (2019) evaluated the effect of bison reintroduction at 0.05 AUM per ha on Lark Sparrow densities and reported that densities were similar to those in cattle-grazed reference sites as measured 2 years after bison reintroduction. In Oklahoma mixed-grass prairies and sand sagebrush, Lark Sparrows seemed to prefer moderately $(0.2$ animal unit per ha from April to August) and heavily grazed ( 0.4 animal unit per ha) pastures over ungrazed pastures (Lusk and others, 2003). In Arizona, Lark Sparrow abundance was significantly higher on grazed than on ungrazed desert grasslands (Bock and Webb, 1984; Bock and others, 1984, 1993; Bock and Bock, 1988).

The establishment of planted grasslands such as CRP may provide suitable habitat for the Lark Sparrow. In a 12-State study of the north-central Plains, Lark Sparrow populations increased after the establishment of CRP fields (Herkert, 2009). Riffell and others (2008) studied the effects of CRP usage by grassland birds across seven ecological regions and found that Lark Sparrow presence was related to the presence of CRP fields across the entire study area, but not by individual region. In Nebraska, Kansas, and Missouri, a 10-percent increase in patch density of new CRP grasslands caused a 1.4-percent decline in Lark Sparrow abundance (Riffell and others, 2010). In Iowa, Schulte and others (2016) examined the effectiveness of planting strips of native perennial vegetation within rowcrops to increase numbers of grassland songbirds. Treatments were 100 percent rowcrop (that is, the reference), 10 percent of area planted to native vegetation in one strip on the footslope, 10 percent in multiple strips on the contour, or 20 percent in multiple strips on the contour; previous land use before experimental manipulation was tame grassland. Overall abundance, species richness, and diversity of grassland birds were higher on native vegetation strips than 
the reference treatment, but the abundance of Lark Sparrows was unaffected by treatments. In the Oklahoma Panhandle, Lark Sparrow habitat increased by 32 percent after the establishment of CRP habitat in the landscape; mean patch size and total edge habitat increased by 34 and 12 percent, respectively (Lungu, 2007).

Little information is available concerning the response of Lark Sparrows to mechanical treatments, such as brush mowing and disking, to control vegetative growth. In southwestern Colorado, mechanical treatments undertaken to improve sagebrush habitat for Gunnison Sage-Grouse (Centrocercus minimus) by removing encroaching woodland species by mechanical and chemical means and by burning had no effect on Lark Sparrow density (Lukacs and others, 2015). Within pinyon-juniper woodlands in central Colorado, thinning of the woodlands by mastication (mechanical cutting and mulching) and hand-thinning increased the occupancy of Lark Sparrows (Magee and others, 2019).

Savannas and grasslands encroached by woody vegetation are suitable habitat for Lark Sparrows, and total removal of woody vegetation may be detrimental. In southeastern Minnesota, Lark Sparrows were more abundant in savannas than in burned woodlands (Au and others, 2008). In an Ohio study in oak savannas, new sites created by land management were readily colonized by Lark Sparrows, but male territory size was significantly larger and the number of young fledged was significantly lower on new sites than on established sites (Grigore, 1999). In Oklahoma and Kansas mixed-grass and sand prairies encroached upon by eastern redcedar (Juniperus virginiana), Lark Sparrow abundance increased with increasing canopy cover of redcedar (Doxon, 2009; Schmidt, 2014). In Arizona, Lark Sparrows were more abundant in grasslands undergoing early invasion by juniper and in developing woodland than in undisturbed native grasslands (Rosenstock and Van Riper, 2001). In another Arizona study within semiarid grasslands undergoing a gradient of woodyplant encroachment by mesquite, Lark Sparrows were most abundant within moderately encroached grasslands (Andersen and Steidl, 2019).

Few studies have evaluated the impact of pesticides on Lark Sparrows. In North Dakota, levels of acetylcholinesterase in Lark Sparrow brains did not differ between areas treated with carbaryl (an acetylcholinesterase inhibitor) bait and untreated areas (George and others, 1992). Bartuszevige and others (2002) measured organochlorine pesticides and metabolites in carcasses of grassland-nesting passerines collected in Illinois; two Lark Sparrow carcasses showed no detectable levels of 17 organochlorine compounds evaluated. Quinn and others (2017) examined the response of grassland birds to multiple measures of agricultural change over a 40-year period along the 41st parallel within Colorado, Wyoming, Nebraska, and Iowa. Within this region and time period, total land area planted to cropland increased 40 percent, biomass yield increased 100 percent, and chemical use increased 500 percent. The abundance of Lark Sparrows declined with increased area farmed and more intensive biomass production but not with chemical use, although the findings were not statistically significant (Quinn and others, 2017). In a Texas study examining the effects on avian density of disking, spraying of the herbicide 2,4,5-Trichlorophenoxyacetic acid $(2,4,5-\mathrm{T})$ about 14 years earlier, and construction of brush shelters, there were no effects on brushland sparrows as a group (Gruver and Guthery, 1986). Lark Sparrows were included in a group with other grassland and brushland sparrows, but the effects on individual species were not examined. In a Texas study examining the effects of applying dichlorodiphenyltrichloroethane (DDT) dust to control Lone Star ticks (Amblyomma americanum), numbers of nesting Lark Sparrows decreased in both the treated and untreated areas (George and Stickel, 1949).

Residential and urban development may impose limits on the abundance of Lark Sparrows (Haire and others, 2000; Lenth and others, 2006; Jongsomjit and others, 2013). In an area of residential development in California, Stralberg and Williams (2002) reported that Lark Sparrow densities were negatively associated with development density; the species would be nearly nonexistent at densities of 0.4 ha per parcel. In Colorado, Lark Sparrow abundance was highest at $<5$ percent urban index, as measured by summing the percentage urban vegetation and percentage buildings and paved area within a rectangular landscape that included the city of Boulder, Colorado, and a 1-km buffer surrounding the City of Boulder Open Space (Haire and others, 2000). In a second study around Boulder, Colo., Lenth and others (2006) evaluated differences in avian density between clustered and dispersed housing developments; although Lark Sparrow densities were higher in clustered developments and undeveloped areas than in dispersed developments, the differences were not significant.

There is limited information on the effects of energy development on Lark Sparrows. In New Mexico, Ortega and Francis (2012) reported that Lark Sparrows were detected at a significantly higher proportion on sites in which gas wells had compressors running during the surveys than on sites in which gas wells with compressors were turned off during the surveys. Between August 1992 and June 2005, remains of 172 species were identified in oil pits (that is, fluid-filled pits and tanks that store waste fluids from oil production) in the United States (Trail, 2006). Remains of 11 Lark Sparrows were identified in oil pits in Kansas, Oklahoma, Texas, and New Mexico. Beston and others (2016) developed a prioritization system for 428 avian species to identify those species most likely to experience population declines in the United States from wind facilities based on the species' current conservation status and the species' expected risk from wind turbines. The Lark Sparrow scored a 2.98 out of nine; 6.83 percent of the Lark Sparrow breeding population in the United States was estimated to be exposed to wind facilities. Wulff and others (2016) examined diurnal flight heights of Lark Sparrows and determined that the species' mean flight height was $8 \mathrm{~m}$, which would likely not be within the rotorswept zone of wind-turbine blades. Loss and others (2013) 
reviewed published and unpublished reports on collision mortality at monopole wind turbines (that is, with a solid tower rather than a lattice tower) in the contiguous United States; one Lark Sparrow mortality was reported at one wind facility. In Oklahoma mixed-grass prairies, Piorkowski (2001) found 11 bird carcasses, including one Lark Sparrow carcass, at a wind facility across two summers. DeVault and others (2014) examined bird use between five pairs of solar arrays and airport grasslands in Arizona, Colorado, and Ohio over 1 year; Lark Sparrows were observed in low numbers at 2 arrays and not observed at airport grasslands.

\section{Management Recommendations from the Literature}

Management activities that reduce sagebrush, scattered trees and shrubs, and edge habitats may be detrimental to Lark Sparrows (Bock and Bock, 1987; Martin and Parrish, 2020). Studies of the impact on burning and grazing indicate that Lark Sparrows are tolerant of these types of disturbances as long as some degree of woody vegetation remains (Robel and others, 1998; Fuhlendorf and others, 2006; Sliwinski and others, 2020). Conversion of grasslands to cropland or monocultures of exotic grasses are not well-tolerated (McMaster and Davis, 1998; Riffell and others, 2010; Earnest and Holmes, 2012).

Intense and infrequent fires are more detrimental than frequent fires in that the former kill the native sagebrush and shrubs that make grasslands suitable for Lark Sparrows (Renwald, 1977; Martin and Parrish, 2020). In shrubsteppe communities, the maintenance of native bunchgrasses decreases the risk of intense and large fires that can occur when native species are converted to cheatgrass monocultures (Earnst and Holmes, 2012). Within burned grasslands, fires that produce the combination of some woody vegetation and bare ground provide preferred substrates for Lark Sparrows (Bock and Bock, 1987; Earnst and Holmes, 2009).

Rangeland practices for livestock production within the tallgrass prairies of the central Great Plains, such as the traditional practice of annual spring burning of pastures in eastern Oklahoma, may be beneficial for Lark Sparrows but may not be beneficial to other grassland species (Fuhlendorf and others, 2006). Fuhlendorf and others (2006) suggested that rotational burning of patches in 1-2 year rotational cycles in pastures may benefit Lark Sparrows, but altering the spatial and temporal pattern of burning to increase variability in vegetation structure will likely benefit more than one grassland bird species. About $300 \mathrm{~km}$ east in Oklahoma sand sagebrush pastures, Holcomb and others (2014) recommended a 3-year fire interval to enhance habitat for Lark Sparrows and other shrubland birds.

In a northern Texas grassland encroached with honey mesquite and cholla cactus, Long and others (2014) reported that repeated applications of dormant-season prescribed burns at 2- and 4-year intervals did not alter shrub density and did not influence Lark Sparrow abundance, although Long and others (2012) reported that daily nest survival was higher in patches burned at 2-year intervals than in patches burned at 4- or 10 -year intervals. Long and others $(2012,2014)$ suggested that the intensity of the prescribed burns was too moderate to influence the degree of shrub encroachment and further reductions would require conducting more-intense burns under conditions of higher biomass or during droughts or the growing season, or would require using chemical or mechanical means to remove shrubs. For central Texas mesquite grasslands in which the rejuvenation of tobosagrass stands was a priority, Renwald (1977) described characteristics of burns that might enhance Lark Sparrow management: conducting burns before Lark Sparrows arrive on the breeding grounds to prevent disruption of breeding activities; conducting burns at moderate temperatures to prevent removal of all woody substrates and provide patches of unburned habitat, both of which are good for nesting Lark Sparrows; and conducting burns at 5-8-year intervals, an interval that eliminates decadent stands of tobosagrass that removes Lark Sparrow foraging areas (Renwald, 1977).

In mixed-grass and tallgrass prairies, moderate-to-heavy grazing is compatible with the vegetation structural requirements of nesting Lark Sparrows, regardless of whether the grazing mammals are cattle (Bock and Webb, 1984; Lusk and others, 2003; Kempema, 2007), bison (Griebel and others, 1998; Wilkins and others, 2019), or a combination of livestock and prairie dogs (Mack, 2017; Geaumont and others, 2019). The creation or maintenance of abundant structural cover with moderate levels of litter accumulation and bare-ground exposure below 12 percent should benefit the species (Lusk and others, 2003). Maintaining a variety of grazing systems may provide heterogeneity of vegetation structure, and maintaining range in good condition will help ensure habitat recovery after drought conditions subside (Kempema, 2007). Sliwinski and others (2019) cautioned that the landscape context within which individual pastures are located may be a more important factor in maintaining structural heterogeneity than grazing system.

Complete removal of woody vegetation, whether through burning, chemical means, or mechanical means, is detrimental to the species (Renwald, 1977). In Arizona, removal of juniper trees from grasslands would have reduced or eliminated Lark Sparrow occupancy (Rosenstock and Van Riper, 2001). Lark Sparrows were present in developing woodland in which average tree density ranged from 42 to 92 trees per ha and tree size averaged 2.7 to $3.4 \mathrm{~m}$ in height. In Nevada sagebrush, McAdoo and others (1989) recommended leaving about 10 percent brush cover for Lark Sparrows. In southern Texas, Davis and others (2019) recommended open grasslands with sparse mesquite mottes of about 10 percent shrub cover per 100 square meters, not exceeding 60 percent.

Within savanna habitats, thinning of trees may be necessary to prevent succession to woodlands (Holoubek and Jensen, 2015). In North Dakota savannas, Cunningham and Johnson (2012) reported that the upper threshold for suitable 
tree cover for Lark Sparrows was 40 percent. In Minnesota, Davis and others (2000) advocated for prescribed burning of savanna habitat to restore vegetation to a condition suitable for Lark Sparrows. In Wisconsin savannas and woodlands, BarMassada and others (2012) recommended maintaining tree canopy cover $<50$ percent to maximize avian species richness. To benefit Lark Sparrows in Kansas, Holoubek and Jensen (2015) recommended that savannas undergoing succession to forest should be thinned to $<25$ percent canopy coverage or $<200$ trees per ha. In contrast, in California, Young and others (2015) recommended practices that maintain oak woodlands for Lark Sparrows; these practices included retaining or planting native species of shrubs and native bunch grasses, protecting young oak trees, and maintaining a ground layer. In South Dakota woodlands of Rocky Mountain juniper, Sieg (1991) suggested monitoring woodland stands for overuse by livestock that cause erosion issues and decreasing livestock numbers, protecting damaged areas with fences, or offering livestock feed away from imperiled woodland stands.

To make oil production waste fluids inaccessible to Lark Sparrows and other birds, Trail (2006) recommended replacing open oil pits with closed tanks or other closed containment systems. If open pits are retained, Trail (2006) recommended increased netting to exclude wildlife. To be effective, netting should be sturdy and supported by a steel frame to provide complete enclosure and should be maintained and monitored to ensure that it remains effective under all conditions.

\section{References}

Andersen, E.M., and Steidl, R.J., 2019, Woody plant encroachment restructures bird communities in semiarid grasslands: Biological Conservation, v. 240, article 108276, p. 1-9. [Also available at https://doi.org/10.1016/j.biocon.2019.108276.]

Au, L., Andersen, D.E., and Davis, M., 2008, Patterns in bird community structure related to restoration of Minnesota dry oak savannas and across a prairie to oak woodland ecological gradient: Natural Areas Journal, v. 28, no. 4, p. 330-341. [Also available at https://doi.org/10.3375/08858608(2008)28[330:PIBCSR]2.0.CO;2.]

Baepler, D.H., 1968, Lark Sparrow (Chondestes grammacus), in Austin, O.L., Jr., ed., Life histories of North American cardinals, grosbeaks, buntings, towhees, finches, sparrows, and allies. Order Passeriformes_-Family Fringillidae. Part two-Genera Pipilo (part) through Spizella: New York, N.Y., Dover Publications, Inc., p. 886-902. [Also available at https://doi.org/10.5479/si.03629236.237.1.]
Barko, V.A., Shaw, J.H., and Leslie, D.M., Jr., 1999, Birds associated with black-tailed prairie dog colonies in southern shortgrass prairie: The Southwestern Naturalist, v. 44, no. 4, p. 484-489. [Also available at https://doi. org/10.2307/3672347.]

Bar-Massada, A., Wood, E.M., Pidgeon, A.M., and Radeloff, V.C., 2012, Complex effects of scale on the relationships of landscape pattern versus avian species richness and community structure in a woodland savanna mosaic: Ecography, v. 35, no. 5, p. 393-411. [Also available at https://doi. org/10.1111/j.1600-0587.2011.07097.x.]

Bartuszevige, A.M., Capparella, A.P., Harper, R.G., Frick, J.A., Criley, B., Doty, K., and Erhart, E., 2002, Organochlorine pesticide contamination in grassland-nesting passerines that breed in North America: Environmental Pollution, v. 117, no. 2, p. 225-232. [Also available at https://doi. org/10.1016/S0269-7491(01)00272-X.]

Best, L.B., 2001, Temporal patterns of bird abundance in cornfield edges during the breeding season: American Midland Naturalist, v. 146, no. 1, p. 94-104. [Also available at https://dx.doi.org/10.1674/0003-0031(2001)146\%5B0094:T POBAI\%5D2.0.CO;2.]

Best, L.B., Campa, H., III, Kemp, K.E., Robel, R.J., Ryan, M.R., Savidge, J.A., Weeks, H.P., Jr., and Winterstein, S.R., 1997, Bird abundance and nesting in CRP fields and cropland in the Midwest-A regional approach: Wildlife Society Bulletin, v. 25, no. 4, p. 864-877.

Beston, J.A., Diffendorfer, J.E., Loss, S.R., and Johnson, D.H., 2016, Prioritizing avian species for their risk of populationlevel consequences from wind energy development: PLoS One, v. 11, no. 3, p. e0150813. [Also available at https://doi. org/10.1371/journal.pone.0150813.]

Bielfelt, B.J., 2013, Invasion by a native grass-Implications of increased dominance of Heteropogon contortus (tanglehead) for grassland birds: Kingsville, Tex., Texas A\&M University-Kingsville, Master's Thesis, 117 p., accessed October 2020 at http://www.montana.edu/litt/documents/ Bielfelt\%20thesis.pdf.

Bock, C.E., and Bock, J.H., 1987, Avian habitat occupancy following fire in a Montana shrubsteppe: Prairie Naturalist, v. 19 , no. 3 , p. $153-158$.

Bock, C.E., and Bock, J.H., 1988, Grassland birds in southeastern Arizona - Impacts of fire, grazing, and alien vegetation, in Goriup, P.D., ed., Ecology and conservation of grassland birds: International Council for Bird Preservation, Technical Publication no. 7, p. 43-58. 
Bock, C.E., and Bock, J.H., 1992, Response of birds to wildfire in native versus exotic Arizona grassland: The Southwestern Naturalist, v. 37, no. 1, p. 73-81. [Also available at https://dx.doi.org/10.2307/3672149.]

Bock, C.E., Bock, J.H., and Bennett, B.C., 1995, The avifauna of remnant tallgrass prairie near Boulder, Colorado: Prairie Naturalist, v. 27, no. 3, p. 147-157.

Bock, C.E., Bock, J.H., and Bennett, B.C., 1999, Songbird abundance in grasslands at a suburban interface on the Colorado High Plains, in Vickery, P.D., and Herkert, J.R., eds., Ecology and conservation of grassland birds of the Western Hemisphere: Studies in Avian Biology, v. 19, p. 131-136.

Bock, C.E., Bock, J.H., Kenney, W.R., and Hawthorne, V.M., 1984, Responses of birds, rodents, and vegetation to livestock exclosure in a semidesert grassland site: Journal of Range Management, v. 37, no. 3, p. 239-242. [Also available at https://dx.doi.org/10.2307/3899146.]

Bock, C.E., Saab, V.A., Rich, T.D., and Dobkin, D.S., 1993, Effects of livestock grazing on Neotropical migratory landbirds in western North America, in Finch, D.M., and Stangel, P.W., eds., Status and management of Neotropical migratory birds: Fort Collins, Colo., U.S. Department of Agriculture, Forest Service, Rocky Mountain Forest and Range Experiment Station, General Technical Report RM-229, p. 296-309.

Bock, C.E., and Webb, B., 1984, Birds as grazing indicator species in southeastern Arizona: The Journal of Wildlife Management, v. 48, no. 3, p. 1045-1049. [Also available at https://doi.org/10.2307/3801466.]

Cable, T.T., Schroeder, R.L., Brack, V., Jr., and Cook, P.S., 1992, Summer bird use of Kansas windbreaks: Prairie Naturalist, v. 24, no. 3, p. 175-184.

Cady, S.M., O'Connell, T.J., Loss, S.R., Jaffe, N.E., and Davis, C.A., 2019, Species-specific and temporal scale-dependent responses of birds to drought: Global Change Biology, v. 25 , no. 8 , p. 2691-2702. [Also available at https://doi. org $/ 10.1111 /$ gcb.14668.]

Cameron, E.S., 1908, The birds of Custer and Dawson counties, Montana: The Auk, v. 25, no. 4, p. 39-56. [Also available at https://doi.org/10.2307/4070565.]

Chapman, R.N., Engle, D.M., Masters, R.E., and Leslie, D.M., Jr., 2004, Grassland vegetation and bird communities in the southern Great Plains of North America: Agriculture, Ecosystems and Environment, v. 104, no. 3, p. 577-585. [Also available at https://doi.org/10.1016/j.agee.2004.01.026.]
Coppedge, B.R., Engle, D.M., Masters, R.E., and Gregory, M.S., 2004, Predicting juniper encroachment and CRP effects on avian community dynamics in southern mixedgrass prairie, USA: Biological Conservation, v. 115 , no. 3 p. 431-441. [Also available at https://doi.org/10.1016/S00063207(03)00160-5.]

Coulter, M., 2008, A multi-scale characterization of Lark Sparrow habitat and the management implications: Bowling Green, Ohio, Bowling Green State University, Master's Thesis, $63 \mathrm{p}$.

Crosby, A.D., Elmore, R.D., Leslie, D.M., Jr., and Will, R.E., 2015, Looking beyond rare species as umbrella speciesNorthern Bobwhites (Colinus virginianus) and the conservation of grassland and shrubland birds: Biological Conservation, v. 186, p. 233-240. [Also available at https://doi. org/10.1016/j.biocon.2015.03.018.]

Cunningham, M.A., and Johnson, D.H., 2011, Seeking parsimony in landscape metrics: Journal of Wildlife Management, v. 75, no. 3, p. 692-701. [Also available at https://doi. org/10.1002/jwmg.85.]

Cunningham, M.A., and Johnson, D.H., 2012, Habitat selection and ranges of tolerance- - How do species differ beyond critical thresholds?: Ecology and Evolution, v. 2, no. 11, p. 2815-2828. [Also available at https://doi.org/10.1002/ ece3.394.]

Cunningham, M.A., and Johnson, D.H., 2016, What you find depends on where you look-Responses to proximate habitat vary with landscape context: Avian Conservation and Ecology, v. 11, no. 2, article 1, p. 1-11. [Also available at https://dx.doi.org/10.5751/ACE-00865-110201.]

Cunningham, M.A., Johnson, D.H., and Svingen, D.N., 2006, Estimates of breeding bird populations in the Sheyenne National Grassland: Prairie Naturalist, v. 38, no. 1, p. 39-61.

Davis, H.T., Long, A.M., Baumgardt, J.A., Campbell, T.A., and Morrison, M.L., 2019, Factors affecting nest success and predator assemblage of breeding birds in semiarid grasslands: Rangeland Ecology and Management, v. 72, no. 2, p. 385-395. [Also available at https://doi. org/10.1016/j.rama.2018.09.005.]

Davis, M.A., and Miller, A., 2018, Savanna restoration using fire benefits birds utilizing dead trees, up to a point: American Midland Naturalist, v. 179, no. 1, p. 94-104. [Also available at https://doi.org/10.1674/0003-0031-179.1.94.] 
Davis, M.A., Peterson, D.W., Reich, P.B., Crozier, M., Query, T., Mitchell, E., Huntington, J., and Bazakas, P., 2000 , Restoring savanna using fire-Impact on the breeding bird community: Restoration Ecology, v. 8, no. 1, p. 30-40. [Also available at https://doi.org/10.1046/j.1526100x.2000.80005.x.]

DeVault, T.L., Seamans, T.W., Schmidt, J.A., Belant, J.L., Blackwell, B.F., Mooers, N., Tyson, L.A., and Van Pelt, L., 2014, Bird use of solar photovoltaic installations at US airports - Implications for aviation safety: Landscape and Urban Planning, v. 122, p. 122-128. [Also available at https://doi.org/10.1016/j.landurbplan.2013.11.017.]

Dinsmore, J.J., Kent, T.H., Koenig, D., Peterson, P.C., and Roosa, D.M., 1984, Iowa birds: Ames, Iowa, Iowa State University Press, 356 p.

Doxon, E.D., 2009, Nesting and feeding ecology of grassland birds in mixed-grass prairie managed with patch-burn techniques: Stillwater, Okla., Oklahoma State University, Ph.D. Dissertation, 273 p., accessed October 2020 at https:// shareok.org/bitstream/handle/11244/6845/Department $\% 20$ of $\% 20 \mathrm{Natural} \% 20$ Resource $\% 20$ Ecology $\% 20$ and $\% 20$ Management_06.pdf? sequence $=1$ \&isAllowed $=\mathrm{y}$.

Drilling, N.E., Sparks, R.A., Woiderski, B.J., and Beason, J.P., 2016, South Dakota Breeding Bird Atlas II—Final Report: Brighton, Colo., Rocky Mountain Bird Observatory, Technical Report M-SDBBA2-07, 595 p., accessed September 2020 at https://gfp.sd.gov/images/WebMaps/Viewer/ WAP/Website/SWGSummaries/SDBBA2\%20Final\%20 Report\%20T-41-R.pdf.

Earnst, S.L., and Holmes, A.L., 2012, Bird-habitat relationships in Interior Columbia Basin shrubsteppe: The Condor, v. 114, no. 1, p. 15-29. [Also available at https://doi. org/10.1525/cond.2012.100176.]

Earnst, S.L., Newsome, H.L., LaFramboise, W.L., and LaFramboise, N., 2009, Avian response to wildlife in Interior Columbia Basin shrubsteppe: The Condor, v. 111, no. 2 , p. 370-376. [Also available at https://doi.org/10.1525/ cond.2009.080109.]

Ellison, K., Ross, J.D., and Bouzat, J.L., 2013, Genetic evidence for mixed maternity at a Lark Sparrow nest: Western Birds, v. 44, no. 2, p. 135-140.

Ely, C.A., 1957, Comparative nesting success of certain south-central Oklahoma birds: Norman, Okla., University of Oklahoma, Master's Thesis, $74 \mathrm{p}$.

Erickson, A.N., 2017, Responses of grassland birds to patchburn grazing in the Flint Hills of Kansas: Manhattan, Kans., Kansas State University, Master's Thesis, 71 p.

Faanes, C., 1983, Breeding birds of wooded draws in western North Dakota: Prairie Naturalist, v. 15, no. 4, p. 173-187.
Faanes, C.A., and Lingle, G.R., 1995, Breeding birds of the Platte River Valley of Nebraska: Jamestown, N. Dak., U.S. Geological Survey, Northern Prairie Wildlife Research Center, $412 \mathrm{p}$.

Fitch, H.S., 1958, Home ranges, territories, and seasonal movements of vertebrates of the Natural History Reservation: University of Kansas Publications, Museum of Natural History, v. 11, no. 3, p. 63-326.

Flanders, A.A., Kuvlesky, W.P., Jr., Ruthven, D.C., III, Zaiglin, R.E., Bingham, R.L., Fulbright, T.E., Hernandez, F., and Brennan, L.A., 2006, Effects of invasive exotic grasses on south Texas rangeland breeding birds: The Auk, v. 123, no. 1, p. 171-182. [Also available at https://dx.doi. org/10.1642/0004-8038(2006)123\%5B0171:EOIEGO\%5D 2.0.CO;2.]

Fleishman, E., Thomson, J.R., Kalies, E.L., Dickson, B.G., Dobkin, D.S., and Leu, M., 2014, Projecting current and future location, quality, and connectivity of habitat for breeding birds in the Great Basin: Ecosphere, v. 5, no. 7, article 82, p. 1-29. [Also available at http://dx.doi. org/10.1890/ES13-00387.1.]

Fortin, M.-J., Keitt, T.H., Maurer, B.A., Taper, M.L., Kaufman, D.M., and Blackburn, T.M., 2005, Species' geographic ranges and distributional limits - Pattern analysis and statistical issues: Oikos, v. 108, no. 1, p. 7-17. [Also available at https://doi.org/10.1111/j.0030-1299.2005.13146.x.]

Friedmann, H., Kiff, L.F., and Rothstein, S.I., 1977, A further contribution to knowledge of the host relations of the parasitic cowbirds: Smithsonian Contributions to Zoology, no. 235, p. 1-75. [Also available at https://dx.doi. org/10.5479/si.00810282.235.]

Fuhlendorf, S.D., Harrell, W.C., Engle, D.M., Hamilton, R.G., Davis, C.A., and Leslie, D.M., Jr., 2006, Should heterogeneity be the basis for conservation? Grassland bird response to fire and grazing: Ecological Applications, v. 16 , no. 5, p. 1706-1716. [Also available at https://dx.doi. org/10.1890/1051-0761(2006)016\%5B1706:SHBTBF\%5D 2.0.CO;2.]

Geaumont, B.A., Hovick, T.J., Limb, R.F., Mack, W.M., Lipinski, A.R., and Sedivec, K.K., 2019, Plant and bird community dynamics in mixed-grass prairie grazed by native and domestic herbivores: Rangeland Ecology and Management, v. 72, p. 374-384. [Also available at https:// doi.org/10.1016/j.rama.2018.10.002.]

George, A.D., O'Connell, T.J., Hickman, K.R., and Leslie, D.M., 2013, Food availability in exotic grasslands-A potential mechanism for depauperate breeding assemblages: The Wilson Journal of Ornithology, v. 125, no. 3, p. 526533. [Also available at https://doi.org/10.1676/13-003.1.] 
George, J.L., and Stickel, W.H., 1949, Wildlife effects of DDT dust used for tick control on a Texas prairie: American Midland Naturalist, v. 42, no. 1, p. 228-237. [Also available at https://doi.org/10.2307/2421797.]

George, T.L., McEwen, L.C., and Fowler, A., 1992, Effects of a carbaryl bait treatment on nontarget wildlife: Environmental Entomology, v. 21, no. 6, p. 1239-1247. [Also available at https://doi.org/10.1093/ee/21.6.1239.]

Goguen, C.B., 2012, Comparison of bird and mammal communities on black-tailed prairie dog (Cynomys ludovicianus) colonies and uncolonized shortgrass prairie in New Mexico: Journal of Arid Environments, v. 80, p. 27-34. [Also available at https://doi.org/10.1016/j.jaridenv.2012.01.001.]

Gorzo, J.M., Pidgeon, A.M., Thogmartin, W.E., Allstadt, A.J., Radeloff, V.C., Heglund, P.J., and Vavrus, S.J., 2016, Using the North American Breeding Bird Survey to assess broadscale response of the continent's most imperiled avian community, grassland birds, to weather variability: The Condor, v. 118 , no. 3, p. 502-512. [Also available at https://doi. org/10.1650/CONDOR-15-180.1.]

Graber, R.R., and Graber, J.W., 1963, A comparative study of bird populations in Illinois, 1906-1909 and 1956-1958: Illinois Natural History Survey Bulletin, v. 28, no. 3, p. 383-528. [Also available at https://doi.org/10.21900/j. inhs.v28.169.]

Griebel, R.L., Winter, S.L., and Steuter, A.A., 1998, Grassland birds and habitat structure in Sandhills prairie management using cattle or bison plus fire: Great Plains Research, v. 8, no. 2 , p. 255-268.

Grigore, M.T., 1999, Breeding ecology and nest site selection in the Eastern Lark Sparrow (Chondestes grammacus grammacus Say) at the edge of its range and implications for land managers: Toledo, Ohio, University of Toledo, Ph.D. Dissertation, $125 \mathrm{p}$.

Gruver, B.J., and Guthery, F.S., 1986, Effects of brush control and game-bird management on nongame birds: Journal of Range Management, v. 39, no. 3, p. 251-253. [Also available at https://doi.org/10.2307/3899061.]

Haire, S.L., Bock, C.E., Cade, B.S., and Bennett, B.C., 2000, The role of landscape and habitat characteristics in limiting abundance of grassland nesting songbirds in an urban open space: Landscape and Urban Planning, v. 48, no. 1-2, p. 65-82. [Also available at https://dx.doi.org/10.1016/ S0169-2046(00)00044-X.]

Helzer, C.J., 1996, The effects of wet meadow fragmentation on grassland birds: Lincoln, Nebr., University of Nebraska, Master's Thesis, $65 \mathrm{p}$.
Helzer, C.J., and Jelinski, D.E., 1999, The relative importance of patch area and perimeter-area ratio to grassland breeding birds: Ecological Applications, v. 9, no. 4, p. 1448-1458. [Also available at https://dx.doi.org/10.2307/2641409.]

Herkert, J.R., 2009, Response of bird populations to farmland set-aside programs: Conservation Biology, v. 23, no. 4, p. 1036-1040. [Also available at https://dx.doi.org/10.1111/ j.1523-1739.2009.01234.x.]

Hickman, K.R., Farley, G.H., Channell, R., and Steier, J.E., 2006, Effects of Old World bluestem (Bothriochloa ischaemum) on food availability and avian community composition within the mixed-grass prairie: The Southwestern Naturalist, v. 51, no. 4, p. 524-530. [Also available at https://doi. org/10.1894/0038-4909(2006)51[524:EOOWBB]2.0.CO;2.]

Hill, R.A., 1976, Host-parasite relationships of the Brownheaded Cowbird in a prairie habitat of west-central Kansas: The Wilson Bulletin, v. 88, no. 4, p. 555-565.

Holcomb, E.D., Davis, C.A., and Fuhlendorf, S.D., 2014, Patch-burn management-Implications for conservation of avian communities in fire-dependent sagebrush ecosystems: The Journal of Wildlife Management, v. 78, no. 5, p. 848856. [Also available at https://doi.org/10.1002/jwmg.723.]

Holoubek, N.S., and Jensen, W.E., 2015, Avian occupancy varies with habitat structure in oak savanna of the southcentral United States: The Journal of Wildlife Management, v. 79 , no. 3, p. 458-468. [Also available at https://doi. org/10.1002/jwmg.849.]

Houston, C.S., and Houston, M.I., 2001, Slow northward spread of the Lark Sparrow: Blue Jay, v. 59, no. 1, p. 40-42. [Also available at https://doi.org/10.29173/bluejay5815.]

Hull, S.D., Robel, R.J., and Kemp, K.E., 1996, Summer avian abundance, invertebrate biomass, and forbs in Kansas CRP: Prairie Naturalist, v. 28, no. 1, p. 1-12.

Igl, L.D., 2009, Breeding bird use of grasslands enrolled in the Conservation Reserve Program in the northern Great Plains: Fargo, N. Dak., North Dakota State University, Ph.D. Dissertation, Fargo, North Dakota, 199 p.

Igl, L.D., and Johnson, D.H., 2007, Brown-headed Cowbird, Molothrus ater, parasitism and abundance in the northern Great Plains: Canadian Field-Naturalist, v. 121, no. 3, p. 239-255. [Also available at https://dx.doi.org/10.22621/ cfn.v121i3.471.]

Igl, L.D., and Kantrud, H.A., 2003, New nesting dates for some breeding birds in North Dakota: Prairie Naturalist, v. 35 , no. 4 , p. $281-285$. 
Intergovernmental Panel on Climate Change, 2000, IPCC special report-Emissions scenarios: United Kingdom, accessed May 2020 at https://www.ipcc.ch/site/assets/ uploads/2018/03/sres-en.pdf.

Jacobson, M.D., Tsakiris, E.T., Long, A.M., and Jensen, W.E., 2011, No evidence for observer effects on Lark Sparrow nest survival: Journal of Field Ornithology, v. 82, no. 2, p. 184-192. [Also available at https://doi.org/10.1111/ j.1557-9263.2011.00321.x.]

Joern, A., 1992, Variable impact of avian predation on grasshopper assemblies in Sandhills grassland: Oikos, v. 64 , no. 3, p. 458-463. [Also available at https://doi. org/10.2307/3545161.]

Johnson, D.H., and Schwartz, M.D., 1993, The Conservation Reserve Program-Habitat for grassland birds: Great Plains Research, v. 3, no. 2, p. 273-295.

Johnson, W.P., Hartman, M., and Thomas, E., 2016. Lark Sparrow builds nest in metal carport: Bulletin of the Texas Ornithological Society, v. 49, no. 1-2, p. 98-99.

Jongsomjit, D., Stralberg, D., Gardali, T., Salas, L., and Wiens, J., 2013, Between a rock and a hard place-The impacts of climate change and housing development on breeding birds in California: Landscape Ecology, v. 28, no. 2, p. 187-200. [Also available at https://doi.org/10.1007/s10980-012-98251.]

Kahl, R.B., Baskett, T.S., Ellis, J.A., and Burroughs, J.N., 1985, Characteristics of summer habitats of selected nongame birds in Missouri: Columbia, Mo., University of Missouri-Columbia, Research Bulletin 1056, 155 p.

Kaspari, M., and Joern, A., 1993, Prey choice by three insectivorous grassland birds-Reevaluating opportunism: Oikos, v. 68, no. 3, p. 414-430. [Also available at https:// doi.org/10.2307/3544909.]

Kempema, S.L.F., 2007, The influence of grazing systems on grassland bird density, productivity, and species richness on private rangeland in the Nebraska Sandhills: Lincoln, Nebr., University of Nebraska, Master's Thesis, 178 p.

Klimkiewicz, M.K., and Futcher, A.G., 1987, Longevity records of North American birds - Coerebinae through Estrildidae: Journal of Field Ornithology, v. 58, no. 3, p. 318-333.

Klute, D.S., Robel, R.J., and Kemp, K.E., 1997, Will conversion of Conservation Reserve Program (CRP) lands to pasture be detrimental for grassland birds in Kansas?: American Midland Naturalist, v. 137, no. 2, p. 206-212. [Also available at https://dx.doi.org/10.2307/2426840.]
Knight, E.C., Mahony, N.A., and Green, D.J., 2016, Effects of agricultural fragmentation on the bird community in sagebrush shrubsteppe: Agriculture, Ecosystems and Environment, v. 223, p. 278-288. [Also available at https://doi. org/10.1016/j.agee.2016.03.011.]

Krannitz, P.G., 2007, Abundance and diversity of shrub-steppe birds in relation to encroachment of ponderosa pine: The Wilson Journal of Ornithology, v. 119, no. 4, p. 655-664. [Also available at https://doi.org/10.1676/06-129.1.]

Krannitz, P.G., and Rohner, C., 2000, Habitat relationships of endangered grassland birds in the South Okanagan, in Darling, I.M., ed., Proceedings of a Conference on the Biology and Management of Species and Habitats at Risk: Victoria, British Columbia, British Columbia Ministry of Environment, Lands and Parks, p. 823-829, accessed October 2020 at http://www.env.gov.bc.ca/wld/documents/so12krannitz. pdf.

Langham, G.M., Schuetz, J.G., Distler, T., Soykan, C.U., and Wilsey, C., 2015, Conservation status of North American birds in the face of future climate change: PLoS One v. 10, no. 9, p. e0135350. [Also available at https://dx.doi. org/10.1371/journal.pone.0135350.]

Lee, S.L., 2006, Post-fire successional effects on breeding grassland birds in mesquite savanna habitats of the Texas Rolling Plains: College Station, Tex., Texas A\&M University, Master's Thesis, 72 p., accessed October 2020 at https://oaktrust.library.tamu.edu/bitstream/ handle/1969.1/4672/etd-tamu-2006C-WISC-Lee. pdf? sequence $=1 \&$ is Allowed $=\mathrm{y}$.

Lenth, B.A., Knight, R.L., and Gilgert, W.C., 2006, Conservation value of clustered housing developments: Conservation Biology, v. 20, no. 5, p. 1445-1456. [Also available at https://doi.org/10.1111/j.1523-1739.2006.00491.x.]

Long, A.M., Jensen, W.E., and Matlack, R.S., 2012, Effects of prescribed burning on avian nest survival in the southern Great Plains: The Journal of Wildlife Management, v. 76, no. 5, p. 899-906. [Also available at https://dx.doi. org/10.1002/jwmg.328.]

Long, A.M., Jensen, W.E., and Matlack, R.S., 2014, Influence of prescribed burning on bird abundance and species assemblage in a semiarid Great Plains grassland: Western North American Naturalist, v. 74, no. 4, p. 396-404. [Also available at https://doi.org/10.3398/064.074.0405.]

Loss, S.R., Will, T., and Marra, P.P., 2013, Estimates of bird collision mortality at wind facilities in the contiguous United States: Biological Conservation, v. 168, p. 201-209. [Also available at https://dx.doi.org/10.1016/j. biocon.2013.10.007.] 
Lukacs, P.M., Seglund, A., and Boyle, S., 2015, Effects of Gunnison Sage-Grouse habitat treatment efforts on associated avifauna and vegetation structure: Avian Conservation and Ecology, v. 10, no. 2, article 7, p. 1-13. [Also available at https://dx.doi.org/10.5751/ACE-00799-100207.]

Lungu, C., 2007, Modeling post-CRP land use for optimum environmental benefits: Stillwater, Okla., Oklahoma State University, Ph.D. Dissertation, 214 p., accessed October 2020 at https://shareok.org/bitstream/handle/11244/7109/ Environmental\%20Sciences\%20Program_17. pdf? sequence $=1 \&$ is Allowed $=\mathrm{y}$.

Lusk, J.J., Wells, K.S., Guthery, F.S., and Fuhlendorf, S.D., 2003, Lark Sparrow (Chondestes grammacus) nest-site selection and success in a mixed-grass prairie: The Auk, v. 120 , no. 1, p. 120-129, accessed December 2020 at https:/academic.oup.com/auk/article/120/1/120/5562248.

Mack, W.M., 2017, Grassland birds-Community dynamics, resource selection, and nest survival on mixed-grass prairie grazed by native colonial and domestic herbivores: Fargo, N. Dak., North Dakota State University, Master's Thesis, 64 p., accessed October 2020 at https://library. ndsu.edu/ir/bitstream/handle/10365/28598/Grassland\%20 Birds \%20Community\%20Dynamics\%2c\%20Resource $\% 20$ Selection $\% 2$ c\%20and $\% 20$ Nest $\% 20$ Survival $\% 20$ on $\% 20$ Mixed-Grass\%20Prairie\%20Grazed\%20by\%20Native\%20Colonial\%20and\%20Domestic\%20Herbivores. pdf? sequence $=1 \&$ isAllowed $=\mathrm{y}$.

Magee, P.A., Coop, J.D., and Ivan, J.S., 2019, Thinning alters avian occupancy in piñon-juniper woodlands: The Condor, v. 121, no. 1, p. 1-17. [Also available at https://dx.doi. org/10.1093/condor/duy008.]

Maher, W.J., 1974, Matador Project-Birds II. Avifauna of the Matador area: Saskatoon, Saskatchewan, University of Saskatchewan, Canadian Committee for the International Biological Programme, Matador Project, Technical Report $58,31 \mathrm{p}$.

Martin, J.W., and Parrish, J.R., 2020, Lark Sparrow (Chondestes grammacus) (ver. 1.0), in Gill, F.B., and Poole, A.F., eds., Birds of the world: Ithaca, N.Y., Cornell Lab of Ornithology, accessed July 2020 at https://birdsoftheworld. $\mathrm{org} /$ bow/species/larspa/cur/introduction. [Also available at https://doi.org/10.2173/bow.larspa.01.]

McAdoo, J.K., Longland, W.S., and Evans, R.A., 1989, Nongame bird community responses to sagebrush invasion of crested wheatgrass seedings: The Journal of Wildlife Management, v. 53, no. 2, p. 494-502. [Also available at https:// dx.doi.org/10.2307/3801155.]
McCoy, T.D., Ryan, M.R., Burger, L.W., Jr., and Kurzejeski, E.W., 2001, Grassland bird conservation-CP1 vs. CP2 plantings in Conservation Reserve Program fields in Missouri: American Midland Naturalist, v. 145, no. 1, p. 1-17. [Also available at https://doi.org/10.1674/00030031(2001)145[0001:GBCCVC]2.0.CO;2.]

McLachlan, M.M., 2007, Habitat use by birds in the northern shortgrass prairie of North America-A local and landscape approach: Stillwater, Okla., Oklahoma State University, Master's Thesis, $87 \mathrm{p}$.

McMaster, D.G., and Davis, S.K., 1998, Non-game evaluation of the Permanent Cover Program: Regina, Saskatchewan, Saskatchewan Wetland Conservation Corporation, 75 p.

McNair, D.B., 1984, Reuse of other species nests by Lark Sparrows: The Southwestern Naturalist, v. 29, no. 4, p. 506509. [Also available at https://doi.org/10.2307/3671012.]

McNair, D.B., 1985, A comparison of oology and nest record card data in evaluating the reproductive biology of Lark Sparrows, Chondestes grammacus: The Southwestern Naturalist, v. 30, no. 2, p. 213-224. [Also available at https://doi. org $/ 10.2307 / 3670735$.]

Miller, R.A., Bond, L., Migas, P.N., Carlisle, J.D., and Kaltenecker, G.S., 2017, Contrasting habitat associations of sagebrush-steppe songbirds in the Intermountain West: Western Birds, v. 48, p. 35-55. [Also available at https://doi. org/10.21199/WB481.3.]

National Geographic Society, 2011, Field guide to the birds of North America (6th ed.): Washington, D.C., National Geographic Society, 576 p.

Newman, G.A., 1970, Cowbird parasitism and nesting success of Lark Sparrows in southern Oklahoma: The Wilson Bulletin, v. 82, no. 3, p. 304-309.

Nixon, A.E., Fisher, R.J., Stralberg, D., Bayne, E.M., and Farr, D.R., 2016, Projected responses of North American grassland songbirds to climate change and habitat availability at their northern range limits in Alberta, Canada: Avian Conservation and Ecology, v. 11, no. 2, article 2, p. 1-14. [Also available at https://dx.doi.org/10.5751/ACE-00866110202.]

Ortega, C.P., and Francis, C.D., 2012, Effects of gas-well compressor noise on the ability to detect birds during surveys in northwest New Mexico, in Francis, C.D., and Blickley, J.L., eds., The influence of anthropogenic noise on birds and bird studies: Ornithological Monographs, no. 74, p. 78-90. [Also available at https://doi.org/10.1525/om.2012.74.1.78.]

Patten, M.A., Reinking, D.L., and Wolfe, D.H., 2011, Hierarchical cues in brood parasite nest selection: Journal of Ornithology, v. 152, p. 521-532. [Also available at https:// doi.org/10.1007/s10336-010-0608-7.] 
Patten, M.A., Shochat, E., Reinking, D.L., Wolfe, D.H., and Sherrod, S.K., 2006, Habitat edge, land management, and rates of brood parasitism in tallgrass prairie: Ecological Applications, v. 16, no. 2, p. 687-695. [Also available at https://dx.doi.org/10.1890/1051-0761(2006)016\%5B0687:H ELMAR\%5D2.0.CO;2.]

Pavlacky, D.C., Jr., Blakesley, J.A., White, G.C., Hanni, D.J., and Lukacs, P.M., 2012, Hierarchical multi-scale occupancy estimation for monitoring wildlife populations: The Journal of Wildlife Management, v. 76, no. 1, p. 154-162. [Also available at https://dx.doi.org/10.1002/jwmg.245.]

Piorkowski, M.D., 2001, Breeding bird habitat use and turbine collisions of birds and bats located at a wind farm in Oklahoma mixed-grass prairie: Stillwater, Okla., Oklahoma State University, Master's Thesis, 100 p.

Prescott, D.R.C., 1997, Avian communities and NAWMP habitat priorities in the northern prairie biome of Alberta: St. Albert, Alberta, Land Stewardship Centre of Canada, NAWMP-029, 41 p.

Puckett, H.L., Brandle, J.R., Johnson, R.J., and Blankenship, E.E., 2009, Avian foraging patterns in crop field edges adjacent to woody habitat: Agriculture, Ecosystems and Environment, v. 131, no. 1-2, p. 9-15. [Also available at https://doi.org/10.1016/j.agee.2008.08.015.]

Quinn, J.E., Awada, T., Trinidade, F., Fulginiti, L., and Perrin, R., 2017, Combining habitat loss and agricultural intensification improves our understanding of drivers of change in avian abundance in a North American cropland anthrome: Ecology and Evolution, v. 7, no. 3, p. 803-814. [Also available at https://doi.org/10.1002/ece3.2670.]

Rand, A.L., 1948, Birds of southern Alberta: Ottawa, Canada, National Museum of Canada, Bulletin no. 111, Biological Series, no. 37, 105 p.

Reinking, D.L., Wolfe, D.H., and Sherrod, S.K., 2009, Nest monitoring, point counts, and habitat of tallgrass prairie breeding birds of northeastern Oklahoma, 1992-1996: Publications of the Oklahoma Biological Survey, v. 9, no. 1, p. $1-12$.

Renwald, J.D., 1977, Effect of fire on Lark Sparrow nesting densities: Journal of Range Management, v. 30, no. 4, p. 283-285. [Also available at https://doi. org/10.2307/3897306.]
Riffell, S., Scognamillo, D., and Burger, L.W., 2008, Effects of the Conservation Reserve Program on Northern Bobwhite and grassland birds: Environmental Monitoring and Assessment, v. 146, no. 1-3, p. 309-323. [Also available at https:// dx.doi.org/10.1007/s10661-007-0082-8.]

Riffell, S., Scognamillo, D., Burger, L.W., Jr., and Bucholtz, S., 2010, Broad-scale relations between Conservation Reserve Program and grassland birds-Do cover type, configuration, and contract age matter?: The Open Ornithology Journal, v. 3, p. 112-123. [Also available at https://dx.doi. org/10.2174/1874453201003010112.]

Rising, J.D., 1974, The status and faunal affinities of the summer birds of western Kansas: The University of Kansas Science Bulletin, v. 50, no. 8, p. 347-388.

Robel, R.J., Hughes, J.P., Hull, S.D., Kemp, K.E., and Klute, D.S., 1998, Spring burning-Resulting avian abundance and nesting in Kansas CRP: Journal of Range Management, v. 51, no. 2, p. 132-138. [Also available at https://dx.doi. org/10.2307/4003197.]

Roberts, A.J., Boal, C.W., Wester, D.B., Rideout-Hanzak, S., and Whitlaw, H.A., 2012, Grassland bird community response to large wildfires: The Wilson Journal of Ornithology, v. 124, no. 1, p. 24-30. [Also available at https://doi. org/10.1676/10-177.1.]

Roberts, A.J., Boal, C.W., and Whitlaw, H.A., 2017, Nesting ecology of grassland birds following a wildfire in the southern Great Plains: The Southwestern Naturalist, v. 62 , no. 1, p. 39-45. [Also available at https://dx.doi. org/10.1894/0038-4909-62.1.39.]

Rosenstock, S.S., and Van Riper, C., III, 2001, Breeding bird responses to juniper woodland expansion: Journal of Range Management, v. 54, no. 3, p. 226-232. [Also available at https://doi.org/10.2458/azu_jrm_v54i3_rosenstock.]

Ross, J.D., Bridge, E.S., Rozmarynowycz, M.J., and Bingman, B.P., 2014, Individual variation in migratory path and behavior among Eastern Lark Sparrows: Animal Migration, v. 2, no. 1, p. 29-33. [Also available at https://doi. org/10.2478/ami-2014-0003.]

Salt, W.R., and Salt, J.R., 1976, The birds of Alberta: Edmonton, Alberta, Hurtig Publishers, 498 p.

Sample, D.W., 1989, Grassland birds in southern Wisconsin-Habitat preference, population trends, and response to land use changes: Madison, Wis., University of Wisconsin, Master's Thesis, 588 p. 
Sauer, J.R., Hines, J.E., Fallon, J.E., Pardieck, K.L., Ziolkowski, D.J., Jr., and Link, W.A., 2014, The North American Breeding Bird Survey, results and analysis 1966-2012 (ver. 02.19.2014): Laurel, Md., U.S. Geological Survey, Patuxent Wildlife Research Center, accessed July 2020 at https://www.mbr-pwrc.usgs.gov/bbs/bbs2012.shtml.

Schmidt, S.W., 2014, Habitat associations of grassland birds along a gradient of eastern redcedar succession in central Kansas: Fort Hays, Kans., Fort Hays State University, Master's Thesis, 108 p., accessed October 2020 at https:// scholars.fhsu.edu/cgi/viewcontent.cgi?article $=1075 \&$ conte $\mathrm{xt}=$ theses.

Schulte, L.A., MacDonald, A.L., Niemi, J.B., and Helmers, M.J., 2016, Prairie strips as a mechanism to promote land sharing by birds in industrial agricultural landscapes: Agriculture, Ecosystems and Environment, v. 220, p. 55-63. [Also available at https://dx.doi.org/10.1016/j. agee.2016.01.007.]

Shaffer, J.A., Igl, L.D., and Johnson, D.H., 2019, The effects of management practices on grassland birds-Rates of Brown-headed Cowbird (Molothrus ater) parasitism in nests of North American grassland birds, chap. PP of Johnson, D.H., Igl, L.D., Shaffer, J.A., and DeLong, J.P., eds., The effects of management practices on grassland birds: U.S. Geological Survey Professional Paper 1842, 24 p., accessed February 2020 at https://doi.org/10.3133/pp1842PP.

Sieg, C.H., 1991, Rocky Mountain juniper woodlands-Yearround avian habitat: Fort Collins, Colo., Rocky Mountain Forest and Range Experiment Station, U.S. Department of Agriculture, Forest Service, Research Paper RM-296, 7 p., accessed October 2020 at https://doi.org/10.5962/bhl. title. 98682 .

Sliwinski, J.S., Powell, L.A., and Schacht, W.H., 2019, Grazing systems do not affect bird habitat on a Sandhills landscape: Rangeland Ecology and Management, v. 72, no. 1, p. 136-144. [Also available at https://doi.org/10.1016/j. rama.2018.07.006.]

Sliwinski, J.S., Powell, L.A., and Schacht, W.H., 2020, Similar bird communities across grazing systems in the Nebraska Sandhills: The Journal of Wildlife Management, v. 84, no. 4, p. 802-812. [Also available at https://doi.org/10.1002/ jwmg.21825.]

Smith, G.A., and Lomolino, M.V., 2004, Black-tailed prairie dogs and the structure of avian communities on the shortgrass plains: Oecologia, v. 138, p. 592-602. [Also available at https://doi.org/10.1007/s00442-003-1465-3.]

Stewart, R.E., 1975, Breeding birds of North Dakota: Fargo, N. Dak., Tri-College Center for Environmental Studies, $295 \mathrm{p}$.
Stralberg, D., and Williams, B., 2002, Effects of residential development and landscape composition on the breeding birds of Placer County's Foothill oak woodland, in Standiford, R.B., McCreary, D., Purcell, K.L., eds., Proceedings of the fifth Symposium on Oak Woodlands - Oaks in California's changing landscape: Albany, Calif., Pacific Southwest Research Station, U.S. Department of Agriculture, Forest Service, General Technical Report PSW-GTR-184, p. 341366, accessed October 2020 at https://www.fs.fed.us/psw/ publications/documents/psw_gtr184/031_Stralberg.pdf.

Stuber, E.F., and Fontaine, J.J., 2018, Ecological neighborhoods as a framework for umbrella species selection: Biological Conservation, v. 233, p. 112-119. [Also available at https://doi.org/10.1016/j.biocon.2018.04.026.]

Suedkamp Wells, K.M., and Fuhlendorf, S.D., 2005, Comparison of microclimate at grassland bird nests with different substrates: Prairie Naturalist, v. 37, no. 1, p. 21-28.

Sullivan, B.L., Wood, C.L., Iliff, M.J., Bonney, R.E., Fink, D., and Kelling, S., 2009, eBird-A citizen-based bird observation network in the biological sciences: Biological Conservation, v. 142 , no. 10 , p. 2282-2292. [Also available at https://doi.org/10.1016/j.biocon.2009.05.006.]

Taylor, P., 2018, Lark Sparrow in Artuso, C., Couturier, A.R., De Smet, K.D., Koes, R.F., Lepage, D., McCracken, J., Mooi, R.D., and Taylor, P., eds., The atlas of the breeding birds of Manitoba, 2010-2014: Winnipeg, Manitoba, Bird Studies Canada, accessed September 2020 at https://www.birdatlas.mb.ca/accounts/speciesaccount. $\mathrm{jsp}$ ?sp=LASP\&lang $=$ en.

Tingley, M.W., Koo, M.S., Moritz, C., Rush, A.C., and Beissinger, S.R., 2012, The push and pull of climate change causes heterogeneous shifts in avian elevational range: Global Change Biology, v. 18, no. 11, p. 32793290. [Also available at https://doi.org/10.1111/j.13652486.2012.02784.x.]

Trail, P.W., 2006, Avian mortality at oil pits in the United States-A review of the problem and efforts for its solution: Environmental Management, v. 38, no. 4, p. 532-544. [Also available at https://doi.org/10.1007/s00267-005-0201-7.]

Tsai, J.-S., Venne, L.S., Smith, L.M., McMurry, S.T., and Haukos, D.A., 2012, Influence of local and landscape characteristics on avian richness and density in wet playas of the southern Great Plains, USA: Wetlands, v. 32, no. 4, p. 605-618. [Also available at https://doi.org/10.1007/ s13157-012-0280-1.]

Tsakiris, E.T., Jacobson, M.D., Long, A.M., and Jensen, W.E., 2013, Abundance and diversity of arthropods in nests of Lark Sparrows (Chondestes grammacus): The Southwestern Naturalist, v. 58, no. 1, p. 113-117. [Also available at https://doi.org/10.1894/0038-4909-58.1.113.] 
Tyler, J.D., and Shackford, J.S., 2002, Vertebrate associates of black-tailed prairie dogs in Oklahoma: Proceedings of the Oklahoma Academy of Science, v. 82, p. 41-47.

Vander Haegen, W.M., Dobler, F.C., and Pierce, D.J., 2000, Shrubsteppe bird response to habitat and landscape variables in eastern Washington, U.S.A.: Conservation Biology, v. 14, no. 4, p. 1145-1160. [Also available at https://doi. org/10.1046/j.1523-1739.2000.99293.x.]

Vos, S.M., and Ribic, C.A., 2013, Nesting success of grassland birds in oak barrens and dry prairies in west central Wisconsin: Northeastern Naturalist, v. 20, no. 1, p. 131-142. [Also available at http://dx.doi.org/10.1656/045.020.0110.]

Walcheck, K.C., 1970, Nesting bird ecology of four plant communities in the Missouri River breaks, Montana: The Wilson Bulletin, v. 82, no. 4, p. 370-382.

Walley, W.J., 1985, Breeding range extension of the Lark Sparrow into west-central Manitoba: Blue Jay, v. 43, no. 1, p. 18-24. [Also available at https://doi.org/10.29173/bluejay4627.]

Wershler, C., Smith, W.W., and Wallis, C., 1991, Status of the Baird's Sparrow in Alberta_-1987/1988 update with notes on other grassland sparrows and Sprague's Pipit, in Holroyd, G.L., Burns, G., and Smith, H.C., eds., Proceedings of the second Endangered Species and Prairie Conservation Workshop: Edmonton, Alberta, Provincial Museum of Alberta, Natural History Occasional Paper, no. 15, p. 87-89.

Wiens, J.A., and Rotenberry, J.T., 1981, Habitat associations and community structure of birds in shrubsteppe environments: Ecological Monographs, v. 51, no. 1, p. 21-41. [Also available at https://dx.doi.org/10.2307/2937305.]
Wilkins, K., Pejchar, L., and Garvoille, R., 2019, Ecological and social consequences of bison reintroduction in Colorado: Conservation Science and Practice, v. 1, no. 2, e. 9. [Also available at https://doi.org/10.1111/csp2.9.]

Williams, M.I., Paige, G.B., Thurow, T.L., Hild, A.L., and Gerow, K.G., 2011, Songbird relationship to shrub-steppe ecological site characteristics: Rangeland Ecology and Management, v. 64, no. 2, p. 109-118. [Also available at https:// dx.doi.org/10.2111/REM-D-10-00076.1.]

Wood, E.M., Pidgeon, A.M., Gratton, C., and Wilder, T.T., 2011, Effects of oak barrens habitat management for Karner blue butterfly (Lycaeides samuelis) on the avian community: Biological Conservation, v. 144, no. 12, p. 3117-3126. [Also available at https://dx.doi.org/10.1016/j.biocon.2011.10.010.]

Wulff, S.J., Butler, M.J., and Ballard, W.B., 2016, Assessment of diurnal wind turbine collision risk for grassland birds on the southern Great Plains: Journal of Fish and Wildlife Management, v. 7, no. 1, p. 129-140. [Also available at https://dx.doi.org/10.3996/042015-JFWM-031.]

Young, A.D., Owens, B., Odell, M., Shake, C., Gilgert, W., and Geupel, G.R., 2015, Using avian focal species to inform rangeland management in California oak woodland, in Standiford, R.B., and Purcell, K.L., eds., Proceedings of the seventh California Oak Symposium-Managing oak woodlands in a dynamic world: Albany, Calif., U.S. Department of Agriculture, Forest Service, Pacific Southwest Research Station, General Technical Report PSW-GTR-251, p. 145156, accessed September 2020 at https://www.fs.fed.us/psw/ publications/documents/psw_gtr251/psw_gtr251_145.pdf.

Zimmerman, J.L., 1993, Birds of Konza-The avian ecology of the tallgrass prairie: Lawrence, Kans., University of Kansas Press, 186 p. 
Table DD1. Measured values of vegetation structure and composition in Lark Sparrow (Chondestes grammacus) breeding habitat by study. The parenthetical descriptors following authorship and year in the "Study" column indicate that the vegetation measurements were taken in locations or under conditions specified in the descriptor; no descriptor implies that measurements were taken within the general study area.

[cm, centimeter; \%, percent; --, no data; >, greater than]

\begin{tabular}{|c|c|c|c|c|c|c|c|c|c|c|c|}
\hline Study & $\begin{array}{l}\text { State or } \\
\text { province }\end{array}$ & Habitat & $\begin{array}{l}\text { Management } \\
\text { practice or } \\
\text { treatment }\end{array}$ & $\begin{array}{l}\text { Vegetation } \\
\text { height } \\
\text { (cm) }\end{array}$ & $\begin{array}{c}\text { Vegetation } \\
\text { height-density } \\
\text { (cm) }\end{array}$ & $\begin{array}{c}\text { Grass } \\
\text { cover } \\
(\%)\end{array}$ & $\begin{array}{c}\text { Forb } \\
\text { cover } \\
(\%)\end{array}$ & $\begin{array}{c}\text { Shrub } \\
\text { cover } \\
(\%)\end{array}$ & $\begin{array}{c}\text { Bare ground } \\
\text { cover } \\
(\%)\end{array}$ & $\begin{array}{c}\text { Litter } \\
\text { cover } \\
(\%)\end{array}$ & $\begin{array}{l}\text { Litter } \\
\text { depth } \\
\text { (cm) }\end{array}$ \\
\hline $\begin{array}{l}\text { Bock and Webb, } \\
1984\end{array}$ & Arizona & Semi-desert grassland & Grazed, ungrazed & $12.9^{\mathrm{a}}$ & -- & 54.2 & 7 & 3.8 & 38.2 & -- & -- \\
\hline $\begin{array}{r}\text { Fuhlendorf and } \\
\text { others, 2006 }\end{array}$ & Oklahoma & Tallgrass prairie & $\begin{array}{l}\text { Annual complete } \\
\text { burn and grazed }\end{array}$ & 14.7 & -- & 63 & 18 & -- & 20.3 & 8 & -- \\
\hline $\begin{array}{r}\text { Fuhlendorf and } \\
\text { others, } 2006^{b}\end{array}$ & Oklahoma & Tallgrass prairie & $\begin{array}{l}\text { Patch-burn and } \\
\text { grazed }\end{array}$ & 21.7 & -- & 55.7 & 19 & -- & 14.7 & 50.3 & -- \\
\hline $\begin{array}{l}\text { Kahl and others, } \\
1985\end{array}$ & Missouri & Tallgrass prairie & Burned & -- & -- & -- & -- & -- & -- & $40-45$ & $0.1-1.0$ \\
\hline $\begin{array}{l}\text { Long and others, } \\
2012^{c}\end{array}$ & Texas & Shortgrass prairie & Two years postburn & 10.1 & -- & 63.2 & 10.5 & -- & 36.8 & -- & -- \\
\hline $\begin{array}{l}\text { Long and others, } \\
2012^{\mathrm{c}}\end{array}$ & Texas & Shortgrass prairie & Four years postburn & 22 & -- & 69.9 & 12.3 & -- & 30 & -- & -- \\
\hline $\begin{array}{l}\text { Long and others, } \\
2012^{c}\end{array}$ & Texas & Shortgrass prairie & Ten years postburn & 26.5 & -- & 75.9 & 16.2 & -- & 23.9 & -- & -- \\
\hline $\begin{array}{l}\text { Lusk and others, } \\
2003 \text { (nests) }\end{array}$ & Oklahoma & Mixed-grass prairie & Multiple & 37.4 & -- & 9.6 & 9.1 & -- & 16 & 11.6 & 0.3 \\
\hline $\begin{array}{l}\text { Renwald, } 1977 \\
\quad \text { (nests) }\end{array}$ & Texas & $\begin{array}{l}\text { Tobosagrass (Hilaria } \\
\text { mutica) }\end{array}$ & Burned & -- & -- & $32^{\mathrm{d}}$ & -- & -- & -- & -- & -- \\
\hline $\begin{array}{l}\text { Walcheck, } 1970 \\
\text { (nest sites) }\end{array}$ & Montana & $\begin{array}{l}\text { Greasewood } \\
\quad \text { (Sarcobatus)-sage- } \\
\text { brush (Artemisia) } \\
\text { shrubland }\end{array}$ & Grazed & -- & -- & $45^{\mathrm{e}}$ & -- & 15 & 31 & -- & -- \\
\hline $\begin{array}{l}\text { Walcheck, } 1970 \\
\text { (nest sites) }\end{array}$ & Montana & $\begin{array}{l}\text { Pine (Pinus)-juniper } \\
\text { (Juniperus) } \\
\text { woodland }\end{array}$ & Grazed & -- & -- & $44^{\mathrm{e}}$ & -- & 18 & 36 & -- & -- \\
\hline Walcheck, 1970 & Montana & $\begin{array}{l}\text { Greasewood-sagebrush } \\
\text { shrubland }\end{array}$ & Grazed & -- & -- & 24 & 25 & 17 & 20 & -- & -- \\
\hline Walcheck, 1970 & Montana & $\begin{array}{r}\text { Pine-juniper } \\
\text { woodland }\end{array}$ & Grazed & -- & -- & 45 & 9 & 18 & 28 & -- & -- \\
\hline Walcheck, $1970^{\circ}$ & Montana & Sagebrush steppe & Grazed & -- & -- & 49 & 6 & 53 & 3 & -- & -- \\
\hline $\begin{array}{l}\text { Williams and others, } \\
2011^{\text {b }}\end{array}$ & Colorado & Sagebrush steppe & Loamy soil & $39.4^{\mathrm{f}}$ & -- & 4.2 & -- & 17.3 & 42 & 42.5 & -- \\
\hline
\end{tabular}


Table DD1. Measured values of vegetation structure and composition in Lark Sparrow (Chondestes grammacus) breeding habitat by study. The parenthetical descriptors following authorship and year in the "Study" column indicate that the vegetation measurements were taken in locations or under conditions specified in the descriptor; no descriptor implies that measurements were taken within the general study area.-Continued

[cm, centimeter; \%, percent; --, no data; >, greater than]

\begin{tabular}{|c|c|c|c|c|c|c|c|c|c|c|c|}
\hline Study & $\begin{array}{l}\text { State or } \\
\text { province }\end{array}$ & Habitat & $\begin{array}{c}\text { Management } \\
\text { practice or } \\
\text { treatment }\end{array}$ & $\begin{array}{c}\text { Vegetation } \\
\text { height } \\
\text { (cm) }\end{array}$ & $\begin{array}{c}\text { Vegetation } \\
\text { height-density } \\
\text { (cm) }\end{array}$ & $\begin{array}{c}\text { Grass } \\
\text { cover } \\
(\%)\end{array}$ & $\begin{array}{c}\text { Forb } \\
\text { cover } \\
(\%)\end{array}$ & $\begin{array}{c}\text { Shrub } \\
\text { cover } \\
(\%)\end{array}$ & $\begin{array}{c}\text { Bare ground } \\
\text { cover } \\
(\%)\end{array}$ & $\begin{array}{c}\text { Litter } \\
\text { cover } \\
(\%)\end{array}$ & $\begin{array}{r}\text { Litter } \\
\text { depth } \\
\text { (cm) }\end{array}$ \\
\hline $\begin{array}{l}\text { Williams and others, } \\
2011^{\mathrm{b}}\end{array}$ & Colorado & Sagebrush steppe & Saline lowland soil & $63.2^{\mathrm{f}}$ & -- & 1.7 & -- & 45.9 & 27.1 & 52.1 & -- \\
\hline $\begin{array}{l}\text { Williams and others, } \\
2011^{\mathrm{b}}\end{array}$ & Colorado & Sagebrush steppe & Sandy soil & $31^{\mathrm{f}}$ & -- & 0.9 & -- & 16 & 39.8 & 40.2 & -- \\
\hline $\begin{array}{l}\text { Williams and others, } \\
2011^{\mathrm{b}}\end{array}$ & Colorado & Sagebrush steppe & Sandy-skeletal soil & $28.9^{f}$ & -- & 3 & -- & 22.4 & 41.6 & 39.5 & -- \\
\hline
\end{tabular}

${ }^{\mathrm{a}}$ Mean grass height.

${ }^{\text {b}}$ The sum of the percentages is $>100 \%$, based on the modified point-quadrat technique as described by the authors.

'The sum of the percentages is $>100 \%$, based on methods described by the author.

${ }^{\mathrm{d}}$ Tobosagrass cover.

'Value represents grass and forb cover combined.

fSagebrush height. 

For more information about this publication, contact: Director, USGS Northern Prairie Wildlife Research Center 8711 37th Street Southeast Jamestown, ND 58401

701-253-5500

For additional information, visit: https://www.usgs.gov/centers/npwrc Publishing support provided by the Rolla Publishing Service Center 
